IZA DP No. 6268

Are All Migrants Really Worse Off

in Urban Labour Markets?

New Empirical Evidence from China

Jason Gagnon

Theodora Xenogiani

Chunbing Xing

December 2011 


\title{
Are All Migrants Really Worse Off in Urban Labour Markets? New Empirical Evidence from China
}

\author{
Jason Gagnon \\ OECD \\ Theodora Xenogiani \\ $O E C D$ and IZA \\ Chunbing Xing \\ Beijing Normal University and IZA
}

Discussion Paper No. 6268

December 2011

\author{
IZA \\ P.O. Box 7240 \\ 53072 Bonn \\ Germany \\ Phone: +49-228-3894-0 \\ Fax: +49-228-3894-180 \\ E-mail: iza@iza.org
}

\begin{abstract}
Any opinions expressed here are those of the author(s) and not those of IZA. Research published in this series may include views on policy, but the institute itself takes no institutional policy positions.

The Institute for the Study of Labor (IZA) in Bonn is a local and virtual international research center and a place of communication between science, politics and business. IZA is an independent nonprofit organization supported by Deutsche Post Foundation. The center is associated with the University of Bonn and offers a stimulating research environment through its international network, workshops and conferences, data service, project support, research visits and doctoral program. IZA engages in (i) original and internationally competitive research in all fields of labor economics, (ii) development of policy concepts, and (iii) dissemination of research results and concepts to the interested public.
\end{abstract}

IZA Discussion Papers often represent preliminary work and are circulated to encourage discussion. Citation of such a paper should account for its provisional character. A revised version may be available directly from the author. 


\section{ABSTRACT}

\section{Are All Migrants Really Worse Off in Urban Labour Markets? New Empirical Evidence from China*}

The rapid and massive increase of rural-to-urban migration in China has drawn attention to the welfare of migrant workers, particularly to their working conditions and pay. This paper uses data from a random draw of the 2005 Chinese national census survey to investigate discrimination in urban labour markets against rural migrants, by comparing their earnings and the sector (formal vs. informal) they work in with those of urban residents and urban migrants. Exploiting differences in their status in the Chinese residential registration system (hukou) we find no earnings discrimination against rural migrants compared with urban residents, contrary to popular belief. In contrast, we find that urban migrants in fact gain a large wage premium by migrating. However, both rural and urban migrants are found to be discriminated out of the formal sector, working in informal jobs and lacking adequate social protection.

JEL Classification: $\quad$ O15, R23, J24, J71

Keywords: migration, China, discrimination, informal employment

Corresponding author:

Theodora Xenogiani

OECD Directorate for Employment, Labour and Social Affairs

Division for Employment Analysis and Policy

2, Rue André Pascal

75775 Paris CEDEX 16

France

E-mail: t.xenogiani@gmail.com

\footnotetext{
* The authors would like to thank the participants in the July 2008 experts' meeting on Migration and Development held in Paris, the Development Centre's internal seminar series in October 2008 and the ESPE Conference in Sevilla in June 2009 for their useful feedback and comments. Chunbing Xing would like to thank Professor Li Shi for his encouragement and support and for the financial support from the Ministry of Education of the People's Republic of China (No. 08JC790008).
} 


\section{Introduction}

The combination of institutional reform, an increasing rural-urban income gap ${ }^{1}$ and the easing of internal migration restrictions (Cai, 2000), have combined to attract millions of rural workers to the urban centres of China. Between 1990 and 2005 more than 100 million migrants migrated from rural to urban areas (MGI, 2009) ${ }^{2}$ and by 2009 they numbered approximately 150 million (Meng and Zhang, 2010). ${ }^{3}$ According to 2005 nationally representative census data, rural migrant workers accounted for more than 20 per cent of the labour force (50 million) in the urban labour market ${ }^{4}$. There is little doubt as to whether this influx of labour contributed to economic growth (Liang, 2001; Song and Zhang, 2003), but concerns have now turned to implications for individual welfare.

The urbanisation process across the world has raised concern in many countries with a particular focus on how migrants fare in the urban labour market. The economic circumstances of urban migrants, for instance, have been reported to be even worse than those of rural peasants (United Nations, 2003) and many governments have indicated that they would prefer to shift population back to rural areas (UN-Habitat, 2007). In China, the situation is exacerbated by a resident registration system (hukou), as most rural migrants retain their rural hukou status, despite the fact that they may spend a significant amount of time in urban areas. Research shows that migrants disproportionately take up jobs in informal sectors, are paid less, are less likely to be covered by urban social security systems. They may even occasionally find it difficult to get their settled salaries from their employers on time and enforced (China Labour Bulletin, 2008). Hence, while the potential for discrimination on wages may be more evident, there may also be discrimination in the general ability to access formal sector jobs - and as consequence access social benefits.

This paper sets out to answer whether there really is any discrimination in China's urban labour markets. Are migrants really worse off relative to urban residents? Our starting point is a common one found in the research literature on discrimination: wage gaps are a result of either differing levels of individual human capital brought to the labour market or from differing sets of skill-prices offered on the market. The question has a notable policy implication. If rural migrants are paid less as a result of lower skills brought to the urban labour market, reforming the urban labour market will have little effect on their well-being, whereas providing them with education and appropriate skills will enable them to exploit better labour market opportunities.

1. The ratio in 2007, for instance, was 3,2 to 1 (China Statistical Yearbook, National Bureau of Statistics of China, 2007).

2 In comparison, there were 191 million international migrants in 2005 (United Nations, 2009).

3 As a consequence of the recent economic crisis, internal migration in China has slowed down, as fewer job opportunities were available in town. However, this was a short-lived effect mainly because of the short term impact of the crisis on the Chinese economy.

4 In some relatively developed coastal regions, such as those of Guangdong and Fujian, the share of migrants is greater than $50 \%$. 
However, if migrants have significantly lower wages compared to urban residents ${ }^{5}$ with similar individual characteristics, the root of the wage gap may be discrimination. In that case, reforming the labour market with the objective of reducing unfair labour market practices would lead to an increase in the welfare of migrants. Investigating differences across migrant sub-groups may provide additional insights into the determinants of discrimination.

We first estimate a multinomial logit model to determine the factors determining whether an individual works in the formal or informal employment sectors and use the results to test for wage discrimination, using a Oaxaca-Blinder (OB) decomposition framework (Blinder, 1973; Oaxaca, 1973). The comparison between the two groups, rural migrants and urban residents, is multifaceted however, as it involves two dimensions of potential discrimination instead of one, and our results hinge on this dichotomy. The first dimension is hukou status (rural vs. urban), while the second is migrant status (migrant vs. urban resident). We therefore introduce another reference group - namely urban migrants ${ }^{6}$ - with which we can distinguish between these two effects. As urban migrants differ from urban residents only in terms of migrant status, we interpret the positive unexplained figure of the $\mathrm{OB}$ decomposition as a premium associated with migration (or a positive self-selection effect); and as urban migrants and rural migrants differ only in hukou status, we interpret the unexplained figure of the $\mathrm{OB}$ decomposition as discrimination against rural hukou status.

As the Chinese urban labour market is highly segmented along formal and informal sectors, we then take into account the distribution of individuals in these sectors. This issue is at the heart of policy preoccupations with respect to the working conditions of rural migrants and in particular their access to decent and secure jobs. In light of this and because sectoral segmentation is on its own an important aspect of labour market success, we also apply an OB decomposition directly to differences in sectoral distribution.

The paper uses a nationally representative dataset, a one-fifth random draw from the 2005 1\% Chinese census sample, to explore the two issues. Results show that most of the income gap between rural migrants and urban residents can be explained by differences in individual characteristics. However, by comparing urban and rural migrants, we find that the presumed inexistence of income discrimination against rural migrants is actually a net effect of discrimination against rural hukou status and a premium labour market effect accrued by migrants. As for sectoral distribution, an OB decomposition indicates that both rural and urban migrants are discriminated out of the formal sector but the extent of this discrimination is larger for rural migrants.

As a result, rural migrants enjoy an income premium from migrating to urban labour markets but face discrimination with respect to access to formal jobs. The main reason that they earn less when compared to urban residents is due to their lower levels of human capital. Increasing the education level of rural migrants and providing them with useful skills will help increase their income and earning opportunities. As both rural and urban migrants face unfair treatment for formal jobs, reforming the labour market, especially by removing barriers such as

5. For the remainder of the text, "urban resident" refers to non-migrant urban residents.

6. Migrants with an urban hukou status moving from one urban region to another. 
the hukou system, can help increase their access to in the formal sector and facilitate earnings mobility for all migrants.

The paper is organised as follows: Section 2 provides a short discussion on the institutional background and a literature review on labour market segmentation in China. Section 3 describes the data. Section 4 presents and discusses the model specification and Section 5 reports our basic empirical results, where we compare rural migrants and urban residents. In Section 6, we present a more profound analysis comparing different groups of migrants. Section 7 discusses policy implications and concludes.

\section{Institutional background and literature review}

The institutional framework of China's rural and urban areas has been covered extensively, with particular emphasis placed on the hukou registration system (see Cai, 2000, Deng and Gustafsson, 2006, de la Rupelle, 2007 and Zhao, 2005). Despite several reforms to the system since the 1970s, deliberate discrimination of migrants in cities remained legal until very recently, with the aim of reducing competition in urban centres (Cai, 2000). One of the arguments for the hukou system was to avoid the creation of slums typical of big cities in developing countries.

Many have argued that the hukou system creates a two-tiered labour market, generating insiders and outsiders (see for instance, Knight and Yueh, 2003). The hukou system essentially limits access to public housing, education, medical and other benefits to those not registered in the town or city in which they are provided. But despite the restrictions, strong job growth in the manufacturing (export) sector over the last twenty years has managed to attract a significant number of rural workers to urban centres. Today, policy-makers in China face a significant challenge in integrating two distinct labour forces, and it is still unclear as to whether they are complementary or competing for the same jobs. While the labour market has remained sufficiently segmented, evidence of increasing competition has been documented (Knight and Yueh, 2004).

Rural-to-urban migrants are divided in two groups: those who have changed their hukou status to urban and those who remain with a rural registration. Migrants with an urban hukou are registered officially as urban residents, a prerequisite to be covered by the urban social security system and to gain access to various forms of public assistance. Moreover, once registered as urban residents, permanent migrants forfeit their rural resident status, their right to agricultural land in their community of origin as well as their voting rights on village affairs. Both anecdotal evidence and academic research (Deng and Gustafsson, 2006, for example) indicate that rural migrants that successfully change their registration to an urban hukou are well integrated in urban society, at least after accumulating experience in the urban labour market over time ${ }^{7}$.

7. Some rural migrants can successfully obtain a permanent urban hukou status after leaving a rural area, and therefore are often deemed "permanent migrants". It should be noted that permanent migrants are different from urban migrants with the latter having moved from other urban areas and hence holding an urban hukou. We do not consider permanent migrants in our paper. 
Alternatively, many rural migrants retain their rural hukou status, not always by choice, and thus retain rights on their rural land and to voice concern in the political affairs of their village of origin. These migrants are less integrated in urban labour markets compared to permanent migrants and less likely to access good jobs that offer social security benefits (Zhao, 2005). As a result, rural migrants with rural hukou status are often paid less on average. Although they may spend a significant amount of time in urban areas, most are not covered by the urban social security system nor entitled to various other social and economic benefits.

To summarise, two differences standout in the hukou system: the type (rural or urban) ${ }^{8}$ and the precise location in which it is registered. Both provide barriers towards fully accessing public goods, such as subsidized housing, education and health services. One way around this is to find a good formal job, in which the employer provides these services. In fact, employers are required to provide social security, but many, perhaps most, do not.

The hukou system thus creates important distortions and increases inequality in the urban Chinese labour market (Whalley and Zhang, 2004) despite the fact that several papers point to migration within China as a natural mechanism for rural-urban income convergence (Lin et al., 2004; Du et al., 2004). In fact, although migrants have been moving to urban labour markets for many years, the hukou system has ensured that the urban labour market remains segmented, opening the possibility of discrimination against those who are not registered in urban centres.

Previous research shows that despite the fact that migrants are positively self-selected ${ }^{9}$, they are discriminated based on their status. Data from the 2002 China Household Income Project (CHIP) shows that migrants themselves perceive to be discriminated against in urban labour markets (Démurger et al., 2008). Both casual observation and existing research (Meng and Zhang, 2001; UNDP, 2005) indicate that a significant share of migrants take up jobs in the informal sector, are paid less and are also less likely to be covered by urban social security systems (Wei, 2007). The lack of social security coverage is likely to contribute to an important decrease in welfare; a report by the China Labour Bulletin (2008), for instance, reported that the current wage gap between urban and rural regions would increase from 3-fold to 6-fold in real terms, if we considered the benefits accrued from social security. Even worse is that migrants occasionally find it difficult to get their settled salaries from their employers on time and enforced $^{10}$. Despite extensive reforms in minimum wage legislation (see The 1994 Labour Law), the large number of migrants working informally ensures that the minimum wage is not binding.

Econometric studies that focus on discrimination in China use data from different regions at different times and ultimately derive different conclusions, in effect making any comparison a difficult task (Zhao, 2005). For instance, Meng and Zhang (2001) find that 51 per cent of the wage gap between urban residents and migrants is due to unexplained factors (interpreted as

8 To be more accurate, the division is agricultural and non-agricultural.

9. For instance, selection has been documented on the basis of level of education, age, health status or gender (Kikuchi et al., 2000; $\mathrm{Wu}, 2008$ ).

10. The China Labour Bulletin (2008) claims that in 2004 there were 114997 labour dispute lawsuits filed by migrants. 
discrimination) while Dinh and Maurer-Fazio (2004) find 25 per cent and Wang (2005) 43 per cent, each using different datasets which focus on different regions of the country. Deng (2007), using the China Household Income Project (CHIP) data collected by the Chinese Academy of Social Sciences (CASS) and which reasonably covers the country, finds that 60 per cent of the income gap originates from unexplained factors.

Although discrimination in China's urban labour markets raise much concern, little has been done to study why discrimination takes place and to better understand the gaps in labour market outcomes between migrants and urban residents ${ }^{11}$.

In this paper we investigate the reason for wage differences in urban labour markets between migrants and urban residents. We use an OB model to decompose the difference between skill levels and skill-prices. Our research contributes to the literature by using a more representative dataset than previous studies, the $1 / 5^{\text {th }}$ random draw from the 2005 1-per cent sample of the national census, which, in addition, allows us to distinguish between work in the formal and the informal sectors. This is a salient feature when studying migration, as other datasets may not fully capture all migrants, especially those working informally. By introducing a sectoral breakdown along informal-formal labour market segmentation, we get a more complete and realistic picture of migrant labour outcomes in urban labour markets.

\section{Data and summary statistics}

The data we use come from a one-fifth random draw of the 2005 1-per cent sample of the national census administered by the Chinese National Bureau of Statistics (NBS). The sample size is around 2.3 million individuals covering 31 provinces, municipalities and autonomous regions. Generally speaking our data are representative of mainland China ${ }^{12}$ and offer several advantages for studying migrant labour market outcomes. An ordinary household survey may be less likely to obtain a representative sample of migrants due to the floating nature of migration and the sampling process. Another advantage of the census data is that it identifies the rural vs. urban origin of migrants, which provides an alternative comparison group.

11. Among the very few, Meng and Zhang (2001) find that educated urban residents are more likely to have a white-collar job or to work in wholesale or retail trade occupations. Moreover, despite wage discrimination against migrants (which can be as high as $50 \%$ ), they find that $82 \%$ of the discrimination is due to inequality between sectors. Meng (2001) finds that migrants with higher levels of education and urban labour experience are more likely to be self-employed in the informal sector. Shi and Zhang (2006) find that the return to education in the urban labour market is around $5.4 \%$, and show that education is important in determining higher wages for migrants in urban centres. Démurger et al. (2008), decompose annual earnings differences between urban residents and rural migrants into four categories (a sectoral effect, a wage effect, an hours worked effect and a population effect) and find that migrant workers have a comparative advantage in working in the private sector while the opposite holds for urban residents. Moreover, the population effect, the underlying individual characteristics of urban residents and migrants, is significantly important, signaling that pre-market rather than on-market factors prevail. 
Two questions in the questionnaire are used to identify migrants: (1) In which location is your hukou registered? and (2) How long ago did you leave this location? We define migrants as those who have left their registered hukou location for more than half a year and divide this group into four categories according to the location where they were living at the time of the survey (city, town or village) and their hukou type (rural or urban). Namely, we define these categories as follows:

- rural-to-rural: individuals with rural hukou status who have moved to another rural area (village or town);

- rural-to-urban: individuals with rural hukou status who have moved to an urban area (city);

- iii) urban-to-rural: individuals with urban hukou status who have moved to a rural area;

- iv) urban-to-urban: individuals with urban hukou status who have moved to another urban area.

Two definitions of informal employment, consistent with the standard ILO statistical guidelines (ILO, 1993; ILO, 2003), are possible with the census data:

- (a) self-employment;

- (b) the absence of a formal labour contract ${ }^{13}$.

As it will be shown, these two mutually exclusive definitions provide a certain degree of heterogeneity within informal employment, yet both are characterised by the lack of social security coverage.

Selected summary statistics are reported in Figure A2 and Tables A3 and A4 in the Annex. In summary, urban residents (non-movers) are gender balanced, quite educated, mostly all married and many work in the formal sector, and particularly in the public sector. Selfemployed workers are typically older, less educated and male, while showing higher income earnings than 'no contract' employees. Wages are lowest for rural migrants and highest for urban migrants. As for employment contracts, rural migrants are mostly in jobs without contracts while urban residents (non-migrants) are the most likely to have jobs with a formal contract.

\section{Model specification}

We use two empirical strategies in this paper. First we employ a multinomial logit model to identify the main factors associated with the probability of being employed in a formal or informal job. Three multinomial logit models are estimated, one each for urban residents, urban migrants and rural migrants with employment sector as the dependent variable. Employment sectors are defined as: $j=$ formal, self-employment and 'no-contract' work.

13. For the remainder of the text we will reference this group as the 'no contract' group. 
Second, we calculate the $\mathrm{OB}$ decomposition for wage gaps between rural migrants and urban residents ${ }^{14}$. The income gap between the two groups can be decomposed into two parts: one due to differences in individual skill levels (the so-called endowment effect) and the other due to the differences in the skill-prices individuals face in the labour market (the price effect). The OB model is estimated in two steps. First, we estimate separate wage equations - one for each group (rural migrants and urban residents) - defining the OLS wage equation for each group as follows:

$$
W_{i}^{g}=\alpha^{g}+X_{i}^{g} \beta^{g}+\varepsilon_{i}^{g} \quad(g=u, m)
$$

where $W_{i}^{g}$ refers to the income (in log form) of individual $i$ and $g=u, m$ refers to urban residents and rural migrants. $X_{i}{ }^{g}$ is a vector of standard Mincerian control variables, including education, age, marital status, gender, province dummies, industry dummies and occupation dummies. $\alpha^{g}$ is the intercept for group $g$.

Next we use the OLS results from $\bar{W}^{g}=\hat{\alpha}^{g}+\bar{X}^{g} \hat{\beta}^{g}$, with the " " " bar on $W$ and $X$ referring to sample means, and $\hat{\alpha}^{g}, \hat{\beta}^{g}$ the OLS estimates for $\alpha^{g}, \beta^{g}$ to difference out the mean wages for both groups. The OB model is then as follows:

$$
\bar{W}^{u}-\bar{W}^{m}=\left(\alpha^{u}-\alpha^{m}\right)+\left(\bar{X}^{u}-\bar{X}^{m}\right) \beta^{u}+\left(\beta^{u}-\beta^{m}\right) \bar{X}^{m}
$$

The second term on the right-hand side, $\left(X^{u}-X^{m}\right) \beta^{u}$, is the wage gap due to differing individual characteristics (such as human capital) in the absence of discrimination. The third term, $\left(\beta^{u}-\beta^{m}\right) X^{m}$, measures the proportion of the relative wage gap due to discrimination. Discrimination is measured as the residual, or the unexplained difference in the regression coefficients.

In addition to wage gaps, we also look at differences in employment in formal and informal sectors. We decompose the gaps in the formal and informal distributions for each group into endowment and price effects ${ }^{15}$ by estimating a linear probability model and use the results to calculate an $\mathrm{OB}$ decomposition based on sector of employment.

\section{Basic empirical results}

\subsection{Discrimination in the formal sector}

Table 1 uses the multinomial logit model results for urban residents in Table A5 in the Annex to predict the counterfactual formal-informal distribution for rural migrants ${ }^{16}$. That is, if rural migrants were treated as urban residents based on their observable characteristics, the distribution would be different. Notably, approximately 10 per cent of rural migrants would be

14. For the moment we only consider differences between rural migrants and urban residents, and let the analysis on urban migrants for Section 6.

15. Or sector-choice structure effect.

16 Estimates were also corrected for self-selection but this did not change the results. 
in formal employment rather than in the 'no contract' group. The share of the self-employed however would not change much. We could expect this to have an effect on the income gap between rural migrants and urban residents.

Table 1. Sectoral Distributions based on Multinomial Logit Regression Results

\begin{tabular}{lll|lll}
\hline \multicolumn{3}{c|}{ Actual distribution } & & \multicolumn{2}{c}{ Predicted distribution } \\
\hline Urban residents & $\begin{array}{l}\text { Rural } \\
\text { migrants }\end{array}$ & Urban migrants & $\begin{array}{l}\text { Rural migrants } \\
\text { urban residents }\end{array}$ & $\begin{array}{l}\text { Urban migrants as } \begin{array}{c}\text { Urban migrants as } \\
\text { urban residents }\end{array} \\
\text { rural migrants }\end{array}$ \\
\hline 0.585 & 0.348 & 0.517 & 0.457 & 0.571 & 0.44 \\
0.118 & 0.175 & 0.147 & 0.17 & 0.105 & 0.162 \\
\hline
\end{tabular}

Samples include those aged 16-60 years old and who are out of school. Observations with no or zero income declared were dropped. The same holds for migrants who migrated for reasons not related to employment.

Source: 2005 1-per cent sample of the Chinese census

\subsection{Income determinants}

We next consider the determinants of income by type of employment (formal work, selfemployment and 'no contract') for both urban residents and rural migrants. The aim of this exercise is to these the difference in the determinants of income between the sectors and between rural migrants and urban residents. The results of the OLS regressions are presented in Table $2^{17}$. For urban residents (the left panel), the age profiles by income vary depending on sector of work; for the formal employment and the 'no contract' workers income levels increase with age, while for the self-employed income first increases and then decreases. For rural migrants, however, all three groups show no significant difference in the income-age profile. In addition, they are similar to that of self-employed urban residents. Their income levels begin to decrease around 25 to 30 years of age.

The returns to education also differ; for urban residents there are no significant differences in returns to education between formal employment and 'no contract' workers, whereas the self-employed have the lowest returns to education. The same is true for rural migrants, where workers with formal employment yield the highest return to education.

Beyond age and education, the urban labour market also rewards gender and marital status differently. Earnings for women are significantly lower than those of men. The gap is much higher for the self-employed than for the formally employed and 'no contract' workers. There are only slight differences in coefficients between urban residents and rural migrants along gender lines.

17 Estimates were also corrected for self-selection but this did not change the results. 
Table 2. OLS Regression Results: dependent variable=log(hourly income)

\begin{tabular}{|c|c|c|c|c|c|c|c|c|c|}
\hline & \multicolumn{3}{|c|}{ Urban residents } & \multicolumn{3}{|c|}{ Rural migrants } & \multicolumn{3}{|c|}{ Urban migrants } \\
\hline & Formal & Self-empl. & No-contract & Formal & Self-empl. & No-contract & Formal & Self- & No-contr \\
\hline \multicolumn{10}{|l|}{$\begin{array}{c}\text { Age 16-20 } \\
\text { omitted }\end{array}$} \\
\hline age: $21-25$ & $0.114^{* * *}$ & $0.113^{* *}$ & $0.093^{* * *}$ & $0.073^{* * *}$ & $0.177^{* * *}$ & $0.117^{* * *}$ & $0.117^{* * * *}$ & 0.006 & $0.130^{* * *}$ \\
\hline age: $26-30$ & $\begin{array}{c}(0.016) \\
0.227^{* * *}\end{array}$ & $\begin{array}{l}(0.045) \\
0.108^{* *}\end{array}$ & $\begin{array}{c}(0.013) \\
0.157^{* * *}\end{array}$ & $\begin{array}{c}(0.009) \\
0.128^{* * * *}\end{array}$ & $\begin{array}{c}(0.036) \\
0.151^{* * *}\end{array}$ & $\begin{array}{c}(0.007) \\
0.138^{* * *}\end{array}$ & $\begin{array}{c}(0.027) \\
0.276^{* * * *}\end{array}$ & $\begin{array}{c}(0.119) \\
0.096\end{array}$ & $\begin{array}{c}(0.023) \\
0.191^{* * *}\end{array}$ \\
\hline & $(0.017)$ & $(0.045)$ & $(0.014)$ & $(0.011)$ & $(0.036)$ & $(0.009)$ & $(0.029)$ & $(0.118)$ & $(0.027)$ \\
\hline age: $31-35$ & $0.280^{* * *}$ & $0.117^{* *}$ & $0.219^{* * *}$ & $0.123^{* * *}$ & $0.167^{* * *}$ & $0.119^{* * * *}$ & $0.296^{* * *}$ & 0.067 & $0.175^{* * *}$ \\
\hline age: $36-40$ & $\begin{array}{c}(0.017) \\
0.307^{* * *}\end{array}$ & $\begin{array}{l}(0.045) \\
0.098^{* *}\end{array}$ & $\begin{array}{c}(0.015) \\
0.239^{* * *}\end{array}$ & $\begin{array}{c}(0.013) \\
0.098^{* * *}\end{array}$ & $\begin{array}{c}(0.037) \\
0.140^{* * *}\end{array}$ & $\begin{array}{c}(0.009) \\
0.094^{* * *}\end{array}$ & $\begin{array}{c}(0.031) \\
0.304^{* * *}\end{array}$ & $\begin{array}{c}(0.119) \\
-0.005\end{array}$ & $\begin{array}{c}(0.030) \\
0.142^{* * *}\end{array}$ \\
\hline age: $41-45$ & $\begin{array}{c}(0.017) \\
0.307^{* * *}\end{array}$ & $\begin{array}{c}(0.046) \\
0.064\end{array}$ & $\begin{array}{c}(0.015) \\
0.236^{* * *}\end{array}$ & $\begin{array}{c}(0.014) \\
0.065^{* * *}\end{array}$ & $\begin{array}{l}(0.037) \\
0.098^{* *}\end{array}$ & $\begin{array}{c}(0.010) \\
0.040^{* * *}\end{array}$ & $\begin{array}{c}(0.034) \\
0.279^{* * * *}\end{array}$ & $\begin{array}{l}(0.121) \\
-0.007\end{array}$ & $\begin{array}{c}(0.033) \\
0.097^{* * *}\end{array}$ \\
\hline age: $46-50$ & $\begin{array}{c}(0.017) \\
0.318^{* * *}\end{array}$ & $\begin{array}{c}(0.046) \\
0.017\end{array}$ & $\begin{array}{c}(0.015) \\
0.262^{* * *}\end{array}$ & $\begin{array}{c}(0.016) \\
0.064^{* * *}\end{array}$ & $\begin{array}{c}(0.038) \\
0.064\end{array}$ & $\begin{array}{c}(0.012) \\
0.012\end{array}$ & $\begin{array}{c}(0.036) \\
0.182^{* * * *}\end{array}$ & $\begin{array}{c}(0.122) \\
-0.012\end{array}$ & $\begin{array}{l}(0.036) \\
0.087^{* *}\end{array}$ \\
\hline & $(0.017)$ & $(0.046)$ & $(0.015)$ & $(0.020)$ & $(0.040)$ & $(0.015)$ & $(0.039)$ & $(0.125)$ & $(0.039)$ \\
\hline age: $51-55$ & $0.363^{* * *}$ & 0.004 & $0.311^{* * *}$ & $0.095^{* * *}$ & 0.054 & -0.003 & $0.197^{* * *}$ & 0.041 & 0.003 \\
\hline & $(0.018)$ & $(0.047)$ & $(0.016)$ & $(0.026)$ & $(0.043)$ & $(0.018)$ & $(0.046)$ & $(0.130)$ & $(0.048)$ \\
\hline age: $55-60$ & $0.379^{* * *}$ & -0.053 & $0.309^{* * *}$ & $-0.092^{* *}$ & -0.042 & $-0.065^{* * *}$ & $0.267^{* * *}$ & -0.096 & -0.038 \\
\hline Female & $\begin{array}{c}(0.019) \\
-0.132^{* * *} \\
(0.003)\end{array}$ & $\begin{array}{c}(0.050) \\
-0.225^{* * *} \\
(0.009)\end{array}$ & $\begin{array}{c}(0.019) \\
-0.164^{* * * *} \\
(0.004)\end{array}$ & $\begin{array}{c}(0.036) \\
-0.136^{* * *} \\
(0.006)\end{array}$ & $\begin{array}{c}(0.052) \\
-0.249^{* * *} \\
(0.011)\end{array}$ & $\begin{array}{c}(0.025) \\
-0.159^{* * *} \\
(0.005)\end{array}$ & $\begin{array}{c}(0.065) \\
-0.164^{* * *} \\
(0.012)\end{array}$ & $\begin{array}{c}(0.145) \\
-0.198^{* * * *} \\
(0.028)\end{array}$ & $\begin{array}{c}(0.061) \\
-0.145^{* * *} \\
(0.013)\end{array}$ \\
\hline \multicolumn{10}{|l|}{$\begin{array}{l}\text { Primary and } \\
\text { below omitted }\end{array}$} \\
\hline Junior middle & $0.178^{* * *}$ & $0.121^{* * *}$ & $0.186^{* * *}$ & $0.158^{* * *}$ & $0.171^{* * *}$ & $0.150^{* * *}$ & $0.214^{* * *}$ & $0.187^{* * *}$ & $0.171^{* * *}$ \\
\hline school & $(0.009)$ & $(0.013)$ & $(0.009)$ & $(0.009)$ & $(0.012)$ & $(0.006)$ & $(0.039)$ & $(0.046)$ & $(0.029)$ \\
\hline Senior middle & $0.366^{* * *}$ & $0.225^{* * *}$ & $0.374^{* * *}$ & $0.368^{* * *}$ & $0.277^{* * *}$ & $0.314^{* * *}$ & $0.444^{* * *}$ & $0.324^{* * *}$ & $0.360^{* * *}$ \\
\hline school & $(0.009)$ & $(0.014)$ & $(0.009)$ & $(0.011)$ & $(0.017)$ & $(0.008)$ & $(0.038)$ & $(0.048)$ & $(0.030)$ \\
\hline College & $0.691^{* * *}$ & $0.529^{* * *}$ & $0.731^{* * *}$ & $0.775^{* * *}$ & $0.472^{* * *}$ & $0.632^{* * *}$ & $0.888^{* * * *}$ & $0.638^{* * *}$ & $0.751^{* * *}$ \\
\hline and above & $(0.009)$ & $(0.023)$ & $(0.010)$ & $(0.018)$ & $(0.059)$ & $(0.019)$ & $(0.039)$ & $(0.060)$ & $(0.033)$ \\
\hline Not married & $\begin{array}{c}0.001 \\
(0.006)\end{array}$ & $\begin{array}{c}-0.061^{* * *} \\
(0.020)\end{array}$ & $\begin{array}{c}-0.034^{* * * *} \\
(0.008)\end{array}$ & $\begin{array}{l}-0.015 \\
(0.009)\end{array}$ & $\begin{array}{c}-0.001 \\
(0.022)\end{array}$ & $\begin{array}{c}-0.055^{* * *} \\
(0.007)\end{array}$ & $\begin{array}{c}0.003 \\
(0.017)\end{array}$ & $\begin{array}{c}0.153^{* * * *} \\
(0.052)\end{array}$ & $\begin{array}{l}-0.032^{*} \\
(0.019)\end{array}$ \\
\hline R-squared & $\begin{array}{c}0.424 \\
128509\end{array}$ & $\begin{array}{l}0.147 \\
25832\end{array}$ & 0.423 & $\begin{array}{l}0.291 \\
32947\end{array}$ & $\begin{array}{l}0.148 \\
16536\end{array}$ & $\begin{array}{l}0.235 \\
45138\end{array}$ & 0.435 & $\begin{array}{l}0.205 \\
3272\end{array}$ & 0.389 \\
\hline
\end{tabular}

$*, * * * * *$ statistically significant at the $10 \%, 5 \%, 1 \%$ levels, respectively.

a) Samples include those aged 16-60 years old and who are out of school. Observations with no or zero income declared were dropped. The same holds for migrants who migrated for reasons not related to employment.

b) Province, industry and occupation dummies are included in the regressions but not reported. Constants are not reported either.

c) Standard errors are reported in brackets.

Source: 1-per cent census data of China (2005).

\subsection{Oaxaca-Blinder decomposition}

Using the results from the OLS exercise on income, we now turn to an OB decomposition between rural migrants and urban residents. The results using the entire sample are shown in the first column of Table 3. If type of employment is not taken into account, nearly 100 per cent of the income gap between rural migrants and urban residents can be attributed to differences in individual characteristics (an endowment effect). We then compare rural migrants and urban residents with respect to formal and informal employment. The results are nearly the same. Within formal employment, 83 per cent of the income gap is due to the endowment effect. For the self-employed, it is 
92 per cent, and for the 'no-contract' employees, 160 per cent. The decomposition results for workers without contracts implies that if rural migrants had the same level of human capital as their urban resident counterparts, their wage would not only be higher, but even higher than the income of urban residents.

The gap between rural migrants and urban residents is mainly due to differences in human capital. However, we are careful in interpreting these results. Our results indicate that human capital levels are very important, but they do not imply that the differences in returns to human capital (both in terms of income and the distribution between formal and informal sectors) are not.

Table 3. Oaxaca-Blinder Decomposition of Income Gaps, 2005

\begin{tabular}{|c|c|c|c|c|c|c|}
\hline & & \multirow[t]{2}{*}{$\begin{array}{l}\text { urban residents } \\
\text { vs. } \\
\text { rural migrants }\end{array}$} & \multirow[t]{2}{*}{$\begin{array}{l}\text { rural vs. } \\
\text { urban } \\
\text { migrants }\end{array}$} & \multirow[t]{2}{*}{$\begin{array}{l}\text { urban residents } \\
\text { vs. } \\
\text { urban migrants }\end{array}$} & \multicolumn{2}{|c|}{$\begin{array}{l}\text { recent } v s . \\
\text { non recent } \\
\text { migrants }\end{array}$} \\
\hline & & & & & rural & urban \\
\hline Total difference & & 0.238 & -0.488 & -0.250 & 0.107 & 0.183 \\
\hline Explained (\%) & & 101.7 & 59.0 & 16.5 & 53.2 & 50.6 \\
\hline Unexplained (\%) & & -1.7 & 41.0 & 83.5 & 46.8 & 49.4 \\
\hline \multirow[t]{3}{*}{ Formal employment } & Difference & 0.252 & -0.604 & -0.351 & 0.121 & 0.179 \\
\hline & Explained (\%) & 82.6 & 67.2 & 38.8 & 59.3 & 55.7 \\
\hline & Unexplained (\%) & 17.4 & 32.8 & 61.2 & 40.7 & 44.3 \\
\hline \multirow[t]{3}{*}{ Self-employed } & Difference & -0.096 & -0.236 & -0.333 & 0.077 & 0.086 \\
\hline & Explained (\%) & 92.3 & 13.4 & 33.6 & 11.8 & 14.0 \\
\hline & Unexplained (\%) & 7.7 & 86.6 & 66.4 & 88.2 & 86.0 \\
\hline \multirow[t]{3}{*}{ No-contract } & Difference & 0.153 & -0.302 & -0.149 & 0.118 & 0.188 \\
\hline & Explained (\%) & 160.0 & 56.0 & -40.0 & 59.6 & 46.6 \\
\hline & Unexplained (\%) & -60.0 & 44.0 & 140.0 & 40.4 & 53.4 \\
\hline \multirow[t]{3}{*}{ Recent migrants } & Difference & & -0.448 & & & \\
\hline & Explained (\%) & & 58.5 & & & \\
\hline & Unexplained (\%) & & 41.5 & & & \\
\hline \multirow[t]{3}{*}{ Non-recent migrants } & Difference & & -0.524 & & & \\
\hline & Explained (\%) & & 57.5 & & & \\
\hline & Unexplained (\%) & & 42.5 & & & \\
\hline
\end{tabular}

a) The results are based on OLS regressions.

b) Samples include those aged 16-60 years old and who are out of school. Observations with no or zero income declared were dropped. The same holds for migrants who migrated for reasons not related to employment.

c) Controls for industry and occupation are included.

Source: 1-per cent census data of China (2005).

\section{Discussion and further tests}

\subsection{Are urban residents the right reference group?}

Section 5 concluded that rural migrants are not discriminated in the urban labour market and that their lower outcomes compared to urban residents are due to low human capital. But the null "unexplained effect" found in the previous section, may be the net outcome of two opposing mechanisms: a premium accrued by migrants (a self-selection) and discrimination associated with their rural hukou status. We therefore introduce another group into the analysis: 
urban migrants. By comparing the income gap between rural and urban migrants, the pure hukou effect can be separated as both groups are migrants but differ by hukou status.

The results of the multinomial logit regressions for the determinants of employment sector for urban migrants can be found in Table A6 in the Annex. A counterfactual prediction (Table 1) shows that if urban migrants were treated as rural migrants at least with respect to formal and informal sectors, there would be fewer urban migrants in the formal sector (from 51.7 per cent to 44 per cent), and more in self-employment and in the 'no-contract' group (from 14.7 per cent to 16.2 per cent, and from 33.6 per cent to 39.8 per cent respectively).

The second column of Table 3 reports OB decomposition results for rural and urban migrants by type of employment. The general results indicate that nearly 60 per cent of the income gap between these two groups can be explained by differences in their individual characteristics and the remaining 40 per cent is due to differences in skill-prices. While these results do not indicate a clear conclusion, we find significant heterogeneity across sectors. In the formal sector, differences in endowments can explain 67 per cent of the income gap whereas in the 'no-contract' group the share of explained gap is only 56 per cent. But the most revealing result is that only 13.4 per cent of the gap in the self-employment group can be explained by observable individual characteristics.

By comparing rural migrants with urban migrants instead of urban residents, we obtain different results. Rural migrants fare worse than the urban migrants not only because they have low levels of human capital but also because they are treated differently due to their rural hukou status $^{18}$. These results indicate that migrants receive a premium for migrating, and this holds true both for rural and urban migrants.

\subsection{Premiums for migrants: urban residents versus urban migrants}

Migration is not a random process. Migrants positively self-select into urban labour markets based on individual human capital characteristics - many of which are unobserved. As such, migrant wages likely include a premium related to these unobserved characteristics. To evaluate the true extent of this "migrant premium", we compare urban migrants with urban residents. Both groups have urban hukou status but differ on migrant status. Hence if human capital levels do not fully explain why urban migrants have higher income levels than urban residents, evidence of a migrant premium can be deduced, as urban migrants are paid better due to skill-prices.

The $\mathrm{OB}$ decomposition in column 3 of Table 3 indicates that not only there is a migrant premium but that it is also large. The overall decomposition shows that 83.5 per cent of the income difference is unexplained. For the decompositions by formal-informal sectors, the unexplained shares are 61.2 per cent, 66.4 per cent, and 140 per cent for the formal sector, selfemployed, and 'no-contract' workers respectively. If urban migrants were treated the same as

18. Clearly, rural hukou status has various implications. For example, we use age as a proxy for potential experience, which is likely to be a poor proxy for rural migrants if what really matters is urban labour market experience. 
urban residents in the formal sector, their wages would be even higher than urban residents with the same observable human capital characteristics.

However, although they enjoy wage premiums in the urban labour market, their advantage does not translate into better jobs. The results in Table 1 indicate that if urban migrants were treated as urban residents in the distribution of formal and informal sectors, urban migrants would figure more prominently in the formal sector ( 57 per cent rather than 52 per cent), and less in self-employment (10.5 per cent rather than 14 per cent). This implies that if urban migrants were treated as urban residents along formal-informal sectors, they would have even higher income levels. This negative effect is overcome by large migration-related wage premiums.

\subsection{Does time since initial migration matter?}

We can think of discrimination and the migrant premium referenced above as the net average effect for all migrants. However, wage premiums for migrants likely differ between migrants. The Harris and Todaro (1970) framework suggests that migrants may first enter the informal labour market while waiting and accumulating experience before the opportunity opens up at a formal sector job. Apart from the type of hukou, differences in earnings may originate from the time workers have spent in the urban labour market. In other words, experience and assimilation may be a factor in the wage premium. Unfortunately, it is very difficult to find a comparable proxy for urban labour market experience for all three groups. In order to evaluate this assimilation effect, we decompose the wage gaps between recent and nonrecent migrants.

For both rural and urban migrants, the duration of their migration episode is important. More than 50 per cent of migrants (rural and urban) have less than 3 years of local urban labour market experience (we call this group recent migrants). It seems true for both rural and urban migrants that self-employed workers tend to have been longer in the new labour market, while the 'no contract' workers tend to be more recent migrants. To see the effect of duration more clearly, we split rural migrants and urban migrants into recent and non-recent sub-groups.

To get a better grasp of the role this plays, we estimate a multinomial logit model for each employment sector dividing recent and non-recent migrants (Table A6 in the Annex) and OLS regressions on the determinants of income for each employment sector (Table 4). Recent and non-recent migrants display different patterns both in terms of determinants of income and sector, for both rural and urban migrants.

The OB decomposition results, reported in Table 3, show that for rural migrants (column 5), 47 per cent of the gap between recent and non-recent migrants is unexplained. In the formal sector and for the 'no-contract' worker group however, the unexplained shares are lower than the overall percentages, which are around 40 per cent. For the self-employed, 88 per cent of the difference between recent and non-recent migrants is unexplained. This means that the experience and assimilation effects are more evident for the self-employed. This is an expected result as setting up a business in an urban area requires financial and social capital which may take time to accumulate. The case for urban migrants is similar. 
Table 4. Determinant of income by sector of employment and duration of migration

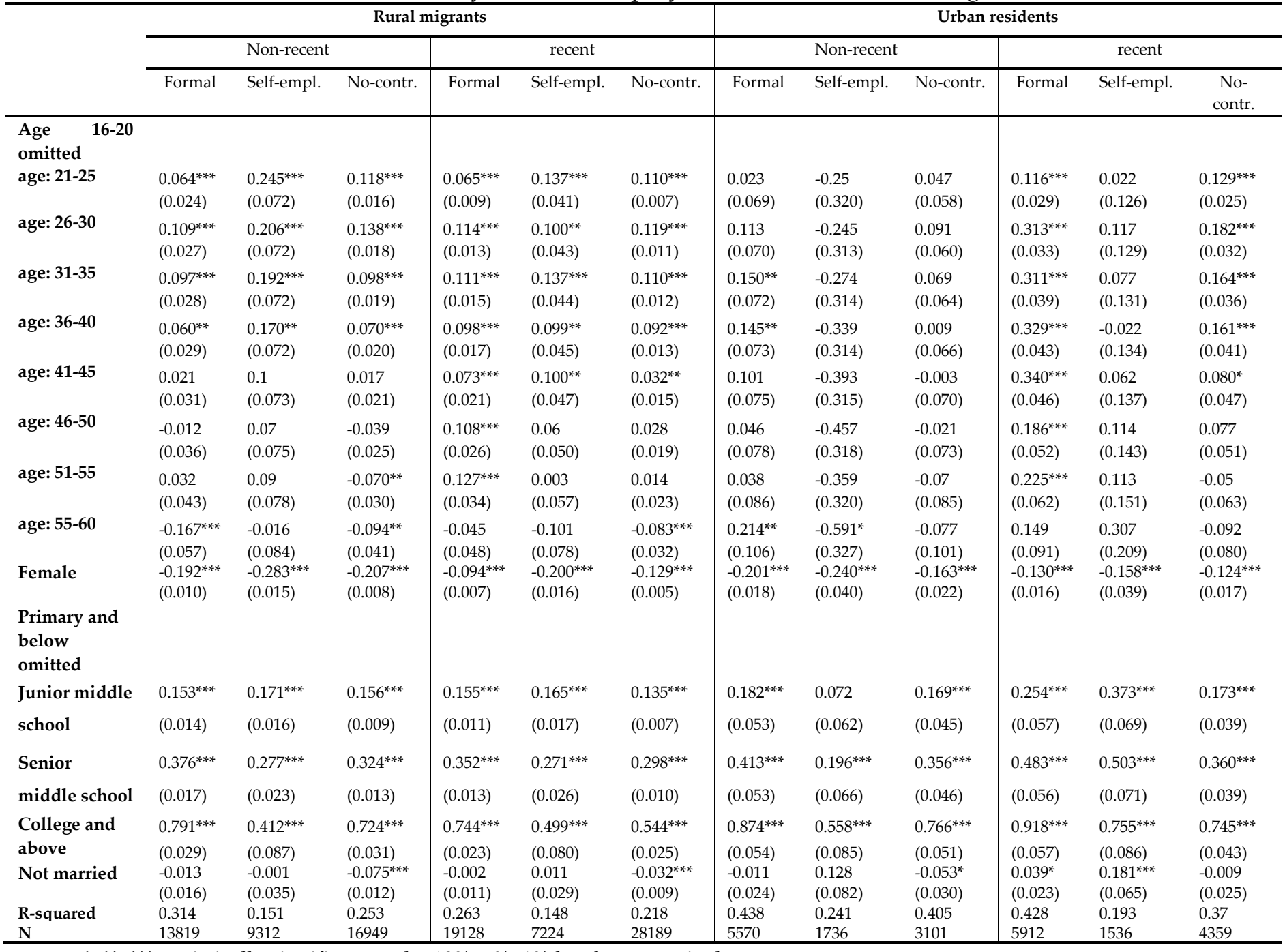

$*, * *,{ }^{* *}$ statistically significant at the $10 \%, 5 \%, 1 \%$ levels, respectively.

a) The dependent variable is the log of hourly income.

b) Samples include those aged 16-60 years old and who are out of school. Observations with no or zero income declared were dropped. The same holds for migrants who migrated for reasons not related to employment.

c) Province, industry and occupation dummies are included in the regressions but not reported. Constants are not reported either.

d) Standard errors are reported in brackets.

Source: 1-per cent census data of China (2005). 
In terms of distribution by formal and informal sectors we turn to our counterfactual predictions in Table 5. If recent migrants were treated as non-recent migrants, there would be more recent migrants in formal sectors or self-employment, and this holds for both rural and urban migrants. Nevertheless the difference between the actual and counterfactual sector distributions is not very large, and this is closely related to the fact that actual sector distributions of recent and non-recent migrants are similar.

Table 5. Sectoral distribution of migrants based on multinomial logit model

\begin{tabular}{|c|c|c|c|c|c|}
\hline \multicolumn{3}{|c|}{ Rural migrants } & \multicolumn{3}{|c|}{ Urban migrants } \\
\hline \multicolumn{2}{|c|}{ Actual distribution } & \multirow{2}{*}{$\begin{array}{l}\text { Predicted distribution } \\
\text { Recent as non-recent }\end{array}$} & \multicolumn{2}{|c|}{ Actual distribution } & \multirow{2}{*}{$\begin{array}{l}\text { Predicted distribution } \\
\text { Recent as non-recent }\end{array}$} \\
\hline Non-recent & Recent & & Non-recent & Recent & \\
\hline 0.345 & 0.351 & 0.359 & 0.535 & 0.501 & 0.524 \\
\hline 0.232 & 0.133 & 0.168 & 0.167 & 0.13 & 0.139 \\
\hline 0.423 & 0.517 & 0.474 & 0.298 & 0.369 & 0.337 \\
\hline
\end{tabular}

Samples include those aged 16-60 years old and who are out of school. Observations of migrants who migrated for reasons not related to employment were dropped.

Source: 2005 1-per cent sample of the Chinese census

\subsection{Decomposing the gaps between sectors}

Our analysis has not, until now, revealed much discrimination in the urban labour market in terms of wages. However, we argue that these results do not imply that there is no discrimination against migrants. Our counterfactual analyses show that, based on individual characteristics, there would be a reshuffling of workers by sector. Even a small degree of discrimination in the formal sector can be quite significant, given the substantial differences that exist in terms of social security coverage, working conditions and pay compared to the informal sector. Moreover, the hukou system does not disqualify migrants from accessing formal jobs per se; both rural and urban migrants have the full right to accede to these jobs. In fact, because the hukou does bar them from accessing public goods, getting a formal job is all the more important for migrants to secure social security, provided by the employer.

To investigate discrimination along formal-informal sector lines we estimate linear probability models on the determinants of having a formal or informal job (available upon request) and use the results to calculate $\mathrm{OB}$ decompositions. The decomposition results are reported in Table 6. In the first two columns, we consider the broad definition of informal employment, including both self-employed and 'no-contract' employees and compare rural migrants with urban residents. The gap between employment type is large. The fraction of informal employment for rural migrants is 33.7 percentage points higher than that of urban residents. The decomposition result shows that only 17 per cent of the difference can be explained by differences in characteristics, while 83 per cent remains unexplained. This is in contrast to the results we had derived with the $\mathrm{OB}$ decomposition results for income gaps, which indicated the dominant role of the endowment effect and a minor role played by sector segmentation. The results here show that there is a significant share of the gap due to 
discrimination in terms of formal and informal sectors, which means migrants may be even worse off in terms of social security coverage and working conditions, even conditional on individual characteristics.

Table 6. Oaxaca-Blinder decomposition of the gap between informal and formal sectors, 2005

\begin{tabular}{|c|c|c|c|c|c|c|c|}
\hline & & \multicolumn{6}{|c|}{ Different definitions of informal employment } \\
\hline & & \multicolumn{2}{|c|}{$\begin{array}{c}\text { Self-employed } \\
\text { and no-contract }\end{array}$} & \multicolumn{2}{|c|}{ Self-employed } & \multicolumn{2}{|c|}{ No contract } \\
\hline \multicolumn{8}{|c|}{ Rural migrants vs. urban residents } \\
\hline & difference & 0.337 & 100 & 0.087 & 100 & 0.250 & 100 \\
\hline & explained & 0.059 & 17 & 0.034 & 39 & 0.025 & 10 \\
\hline & unexplained & 0.278 & 83 & 0.053 & 61 & 0.226 & 90 \\
\hline \multicolumn{8}{|c|}{ Urban migrants $v s$. urban residents } \\
\hline & difference & 0.166 & 100 & 0.057 & 100 & 0.109 & 100 \\
\hline & explained & 0.028 & 17 & -0.005 & -9 & 0.033 & 30 \\
\hline & unexplained & 0.138 & 83 & 0.062 & 109 & 0.076 & 70 \\
\hline \multicolumn{8}{|c|}{ Urban migrants vs. rural migrants } \\
\hline \multirow[t]{3}{*}{ Total } & difference & -0.171 & 100 & -0.030 & 100 & -0.141 & 100 \\
\hline & explained & -0.087 & 51 & -0.007 & 23 & -0.080 & 57 \\
\hline & unexplained & -0.084 & 49 & -0.023 & 77 & -0.061 & 43 \\
\hline \multirow[t]{3}{*}{ Recent migrants } & difference & -0.189 & 100 & -0.065 & 100 & -0.124 & 100 \\
\hline & explained & -0.099 & 53 & -0.038 & 59 & -0.061 & 49 \\
\hline & unexplained & -0.090 & 47 & -0.027 & 41 & -0.063 & 51 \\
\hline \multirow[t]{3}{*}{ Non-recent migrants } & difference & -0.153 & 100 & -0.005 & 100 & -0.149 & 100 \\
\hline & explained & -0.072 & 47 & 0.013 & -267 & -0.084 & 57 \\
\hline & unexplained & -0.082 & 53 & -0.017 & 367 & -0.064 & 43 \\
\hline \multicolumn{8}{|c|}{ Recent vs non-recent migrants } \\
\hline \multirow[t]{3}{*}{ rural migrants } & difference & 0.014 & 100 & -0.087 & 100 & 0.101 & 100 \\
\hline & explained & -0.007 & -52 & -0.059 & 67 & 0.052 & 51 \\
\hline & unexplained & 0.021 & 152 & -0.028 & 33 & 0.050 & 49 \\
\hline \multirow[t]{3}{*}{ Urban migrants } & difference & 0.049 & 100 & -0.027 & 100 & 0.076 & 100 \\
\hline & explained & 0.014 & 29 & -0.024 & 91 & 0.039 & 51 \\
\hline & unexplained & 0.035 & 71 & -0.002 & 9 & 0.037 & 49 \\
\hline
\end{tabular}

a) The decomposition results are based on a Linear Probability Model.

b) Samples include those aged 16-60 years old and who are out of school. Observations with no or zero income declared were dropped. The same holds for migrants who migrated for reasons not related to employment.

Source: 1-per cent census data of China (2005).

Taking into account that the overall sector distribution gap between urban migrants and urban residents is smaller than that between rural migrants and urban residents (16.6 as opposed to 33.7 percentage points), the extent of discrimination against urban migrants is smaller. It should be noted that urban migrants enjoy the highest average income level, and that they are better (not worse) off conditional on their characteristics in terms of income. However, the results here show that they are still discriminated out of the formal sector.

We then compare rural migrants and urban migrants. The results are also as expected. As these two groups are both migrants, differences in characteristics can explain a larger share (around 50 per cent) of the gap between sectors they work in. Still, half of the gap is due to unexplained factors. We interpret this as discrimination against rural hukou status. We also consider recent and non-recent migrants separately but the results do not change much. The final 
decomposition exercise for these two groups is to compare recent and non-recent migrants for each group separately. The results indicate a large share of discrimination against recent migrants. As gaps between recent and non-recent migrants are not very large, the decomposition results are of minor importance. However, because we use a broad definition of informal employment, the small gaps may be caused by composition change within the broad informal employment definition.

In the next four columns of Table 6, we consider self-employment and 'no-contract' employees separately. The general pattern is similar to the one found in the first two columns, but with a slight variation. There are at least two points worth mentioning. First, due to the small fraction of self-employment in all three groups, the difference between groups is relatively small, especially when we compare non-recent rural and urban migrants. Second, when we compare recent and non-recent migrants, there are larger sector distribution changes than under the broad informal definition. For both rural and urban migrants, the fraction of self-employed is larger for non-recent migrants than for recent migrants, and the fraction of 'no-contract' employees is smaller.

\section{Conclusions}

In this paper we use a nationally representative sample of individuals to investigate how rural migrants fare in the urban labour market in China. This paper contributes to the existing literature in several important ways. First, our data is nationally representative and is better at capturing a representative sample of rural migrants. Second, we distinguish among different groups of migrants instead of comparing only rural migrants and urban residents. In particular, we add urban migrants in our analysis, and this allows us to separate the rural hukou effect from the migrant premium effect. Third, we consider sectoral segmentation in terms of formal and informal employment, which is an important dimension of labour market outcomes of rural migrants in Chinese cities.

The main finding in this paper is in stark difference to those in the existing literature. When we compare rural migrants with urban residents, nearly 100 per cent of the difference can be explained by differences in characteristics, which means the skill-price effect is almost negligible. The comparison between urban residents and rural migrants is two-fold however. They differ in type of hukou and on migrant status. The comparison between rural migrants and urban migrants gives a different picture however as they differ in type of hukou but not on migrant status. 40 per cent of the income gap is unjustified. Given the fact that hukou status is the only difference between these two groups conditional on other personal characteristics (and migrant status), this exercise is more appropriate for us to detect discrimination against rural hukou status. By comparing urban migrants with urban residents, we find significant "migrant premiums". Here the groups do not differ by hukou type but by migrant status. We therefore presume that the result of no discrimination we find from the comparison between rural migrants and urban residents is the net effect of a discrimination against rural hukou status and the premium effect accrued by migrants. 
Although formal-informal sector segmentation plays a minor role in explaining the income gap, it is important in terms of social security and working conditions and therefore the gap in sectors in its own right is worth investigating. An OB decomposition indicates that migrants (both rural and urban) are discriminated out of the formal sector (more than 80 per cent is unexplained). The extent of discrimination is larger for rural migrants indicating a further discrimination against rural hukou status taken the magnitude of the gap. The decomposition for differences between sector distributions complements the income decomposition in a very important way.

There are of course limitations in the approach taken in this paper. The first difficulty is choosing the appropriate reference group. We take a step forward by using urban migrants as an additional reference group. However, this method is also not without problems as rural migrants and urban migrants may be different in unobservable characteristics other than their hukou status, even conditional on the characteristics we do control for. Another difficulty is measurement error which is especially salient when we are comparing urban residents (migrants) with rural migrants. Finally, age (even potential experience) is a poor proxy for urban labour market experience for rural migrants.

The policy implications of our results are clear. In terms of income, rural migrants enjoy migrant premiums and suffer discrimination at the same time. Generally speaking, however, the reason they may be worse off when compared to urban residents is due to their lower levels of human capital. Increasing education levels of rural migrants and providing them with training and relevant urban labour market skills will help increase their earning opportunities. As both rural and urban migrants face unfair treatment in sector choice, reforming the labour market, notably removing barriers to mobility between sectors, may help increase formal employment and well-being.

Discrimination against rural hukou status is evident in our study and ideally a complete cancelation of the system would eventually lead to a more equal treatment on the labour market. This, however, may not be practically feasible and in fact remains a central focus of debate in China. What is perhaps more pressing is to ensure that migrants have access to basic social services, even in cases where they are employed informally. Presently those without such coverage face exorbitant costs for health services and in sending their children to urban schools. Furthermore, for migrants who systematically move for jobs, obtaining urban social security coverage is futile as social security systems are for the most part non-portable and expensive. In terms of schooling and childcare, many migrants leave their children back home in the rural parts of China, in effect putting more pressure on household members left-behind and adding to the already existing social strain caused by migration. 


\section{References}

Blinder, A. (1973), "Wage Discrimination: Reduced Form and Structural Estimates", The Journal of Human Resources, Vol. 8, No. 4, pp. 436-455.

Cai, F. (2000), “The Invisible Hand and Visible Feet: Internal Migration in China”, World Economy and China, No. 5.

China Labour Bulletin (2008), “Wages in China”, www.china-labour.org.hk, February.

De La Rupelle, M. (2007), “Le contrôle des migrations en Chine : un atout économique?”, mimeo.

Démurger, S., M. Gurgand, L. Shi And Y. Ximing (2008), “Migrants as second-class workers in urban China? A decomposition analysis", PSE Working Papers 2008-20, PSE (Ecole normale supérieure).

Deng, Q. (2007), “Earnings Differential between Urban Residents and Rural Migrants: Evidence from Oaxaca-Blinder and Quantile Regression Decompositions", Chinese Journal of Population Science, No. 2, (in Chinese).

Deng, Q. And B. Gustafsson (2006), “China's Lesser Known Migrants”, IZA Discussion Paper No. 2152.

Dinh, N. And M. Maurer-Fazio (2004), “Differential Rewards to, and Contributions of, Education in Urban China's Segmented Labor Markets", The Pacific Economic Review, Volume 9, No.3, pp. 173-189.

Du Y., A. Park And S. Wang (2004), “Is Migration Helping China's Poor?”, Paper prepared for the Conference on Poverty, Inequality, Labour Market and Welfare Reform in China, Australia National University, 25-27 August 2004.

Gagnon, J., T. Xenogiani and C. Xing (2009), “Are all Migrants Really Worse off in Urban Labour Markets?: New empirical evidence from China", OECD Development Centre Working Papers 278, OECD Publishing.

Harris J., and M. Todaro (1970), “Migration, Unemployment, and Development: A TwoSector Analysis", American Economic Review, Vol. 60, pp. 126-142.

ILO (1993), Statistics of employment in the informal sector, Report for the XVth International Conference of Labour Statisticians - Geneva 19-28 January 1993, 91 pp.

ILO (2003), Report 1, General Report, 17th International Conference of Labour Statisticians, Geneva, 24 November - 3 December 2003, 100 pp.

Kikuchi, M., A. Maruyama And T. Wang (2000), "Rural-Urban Migration and Labor Markets in China: A Case Study in a Northeastern Province", The Developing Economies, Vol.38(1), pp.80-104.

Knight, J. And L.Yueh (2003), "Job Mobility of Residents and Migrants in Urban China", Economics Series Working Papers 163, University of Oxford, Department of Economics. 
Knight, J. And L. Yueh (2004), “Urban Insiders versus Rural Outsiders: Complementarity or Competition in China's Urban Labour Market?", Economics Series Working Papers 217, University of Oxford, Department of Economics.

Liang, Z. (2001), “The Age of Migration in China”, Population and Development Review, Vol. 27, No. 3 pp. 499-524.

Lin, J., G. Wang And Y. Zhao (2004), "Regional Inequality and Labor Transfers in China", Economic Development and Cultural Change, 52(3), 87-603.

Meng, X. (2001), "The Informal Sector and Rural-Urban Migration: A Chinese Case Study", Asian Economic Journal, 15:1, pp.71-89.

Meng, X. and D.Zhang (2010), “Labour Market Impact of Large Scale Internal Migration on Chinese Urban 'Native' Workers", mimeo.

Meng, X. And J. Zhang (2001), "The Two-Tier Labor Market in Urban China: Occupational Segregation and Wage Differentials between Urban Residents and Rural Migrants in Shanghai", Journal of Comparative Economics, Elsevier, vol. 29(3), pages 485-504.

MGI (2009), "Preparing for China's Urban Billion”, McKinsey Global Institute, March.

National Bureau Of Statistics Of China, (2007), China Statistical Yearbook, 2007, China Statistics Press, Beijing.

Oaxaca, R. (1973), "Male-Female Wage Differentials in Urban Labor Markets", International Economic Review, Vol. 14, No. 3, pp. 693-709.

Shi, X. And H. Zhang (2006), "Education, Experience and Income of Rural Migrants", World Economic Papers, No. 2, (in Chinese).

Song, S. And H. Zhang (2003), "Rural-urban migration and urbanization in China: Evidence from time-series and cross-section analyses", China Economic Review, Elsevier, vol. 14(4), pages 386-400.

UNDP (2005), "China Human Development Report 2005: Development with Equity", United Nations Development Programme.

UN-Habitat (2007), “The State of the World's Cities Report 2006-2007”, London.

United Nations (2003), “State of World Population 2007: Unleashing the potential of urban growth", New York.

United Nations (2009), “International Migration Report 2006: A Global Assessment", Department of Economic and Social Affairs, New York.

Wang, M. (2005), “Employment Opportunities and Wage Gaps in the Urban Labor Market: A study of the employment and wages of migrant laborers", Social Sciences in China, No. 5. (in Chinese).

Wei, Y. (2007), "Rural-Urban Migrant Workers in China: The vulnerable group in cities", Paper presented at the $6^{\text {th }}$ Berlin Roundtables on Transnationality on "Population Politics and Migration" held on 14-19 February 2007, Berlin, Germany. 
Whalley, J. and S. Zhang (2004), "Inequality Change in China and (Hukou) Labour Mobility Restrictions", NBER Working Papers 10683, National Bureau of Economic Research, Inc.

$\mathrm{Wu}$, Z. (2008), "Self-selection and Earnings of Migrants: Evidence from Rural China", Osaka School of International Public Policy Discussion Paper 08-25.

Zhao Z. (2005), “Migration, Labour Market Flexibility, and Wage Determination in China: a Review", Labour and Demography, 0507009, EconWPA. 


\section{Annex}

\section{A1. Data description}

Table A1. The 1-per cent census data of China (2005)

\begin{tabular}{llll}
\hline & Sample size & Calculated national population & Population from CSY \\
\cline { 2 - 4 } & 2585481 & 1292740500 & 1307560000 \\
male & 50.15 & 50.15 & 51.53 \\
female & 49.85 & 49.85 & 48.47 \\
\hline
\end{tabular}

Source: Authors' calculations based on the 1-per cent census data of China (2005), and China Statistical Yearbook (2006).

Table A2. Characteristics of the different types of migrants in China

\begin{tabular}{lllll}
\hline & \multicolumn{4}{c}{ Four types of migrants } \\
\cline { 2 - 5 } Why did you leave your hukou registration location? & rural-rural & rural-urban & urban-rural & urban-urban \\
\hline For job or business & 49.45 & 60.81 & 18.53 & 19.65 \\
Job change & 0.4 & 0.61 & 7.92 & 6.22 \\
Employed & 0.11 & 0.16 & 2.66 & 1.52 \\
Training & 1.26 & 4.05 & 1.55 & 4.01 \\
Move house (change living place) & 2.01 & 2.75 & 4.12 & 22.5 \\
Marriage & 18.77 & 5.18 & 11.83 & 9.14 \\
Move with relatives & 11.8 & 15.32 & 16.38 & 15.41 \\
Move to live with relatives or friends & 10.5 & 6.74 & 14.55 & 8.97 \\
Temporary hukou change & 1.06 & 0.37 & 9.62 & 4.08 \\
On a business trip & 0.37 & 0.37 & 0.26 & 0.24 \\
Others & 4.28 & 3.64 & 12.58 & 8.25 \\
Weighted sample size & & & & 116790 \\
$\quad$ Unweighted sample size & 38724 & 159497 & 12545 & 87315 \\
\hline
\end{tabular}

a) Migrants are defined as those who have left their registration place for more than 6 months.

b) Categories 2 and 3 are mainly for those working in the public sector.

Source: 1-per cent census data of China (2005). 
Figure A1. National Representativeness of the Sample

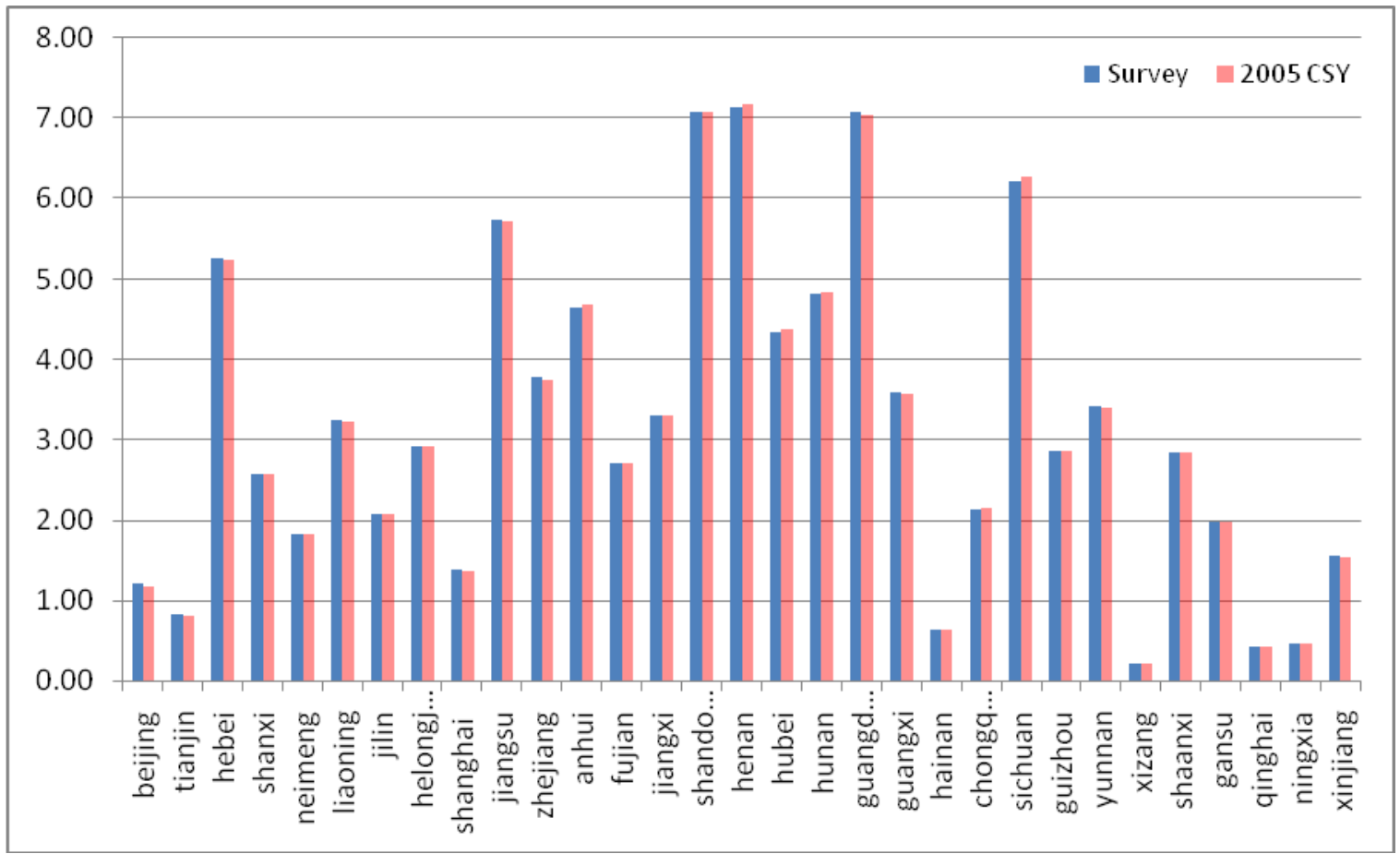

Source: Authors' calculations based on the 1-per cent census data of China (2005) and China Statistical Yearbook (2006). 
Table A3. Summary Statistics

\begin{tabular}{|c|c|c|c|c|c|c|c|c|c|c|c|c|}
\hline & \multicolumn{4}{|c|}{ Urban residents } & \multicolumn{4}{|c|}{ Rural migrants } & \multicolumn{4}{|c|}{ Urban migrants } \\
\hline & total & formal & $\begin{array}{l}\text { self- } \\
\text { empl. }\end{array}$ & $\begin{array}{l}\text { no } \\
\text { contr. }\end{array}$ & total & formal & $\begin{array}{l}\text { self- } \\
\text { empl. }\end{array}$ & $\begin{array}{l}\text { no } \\
\text { contr. }\end{array}$ & total & $\begin{array}{l}\text { forma } \\
1\end{array}$ & $\begin{array}{l}\text { self- } \\
\text { empl. }\end{array}$ & $\begin{array}{l}\text { no } \\
\text { contr. }\end{array}$ \\
\hline $\begin{array}{l}\text { Age } \\
\text { Education levels }\end{array}$ & 39.9 & 40.7 & 39.1 & 37.1 & 30.5 & 29.6 & 3.8 & 29.1 & 32.5 & 32.4 & 36.8 & 30.5 \\
\hline Primary and below & 0.10 & 0.11 & 0.15 & 0.06 & 0.21 & 0.17 & 0.31 & 0.22 & 0.06 & 0.04 & 0.10 & 0.06 \\
\hline $\begin{array}{l}\text { Junior middle } \\
\text { school }\end{array}$ & 0.37 & 0.35 & 0.53 & 0.34 & 0.62 & 0.62 & 0.57 & 0.64 & 0.32 & 0.26 & 0.46 & 0.38 \\
\hline $\begin{array}{l}\text { Senior middle } \\
\text { school }\end{array}$ & 0.31 & 0.32 & 0.28 & 0.32 & 0.15 & 0.18 & 0.11 & 0.13 & 0.36 & 0.36 & 0.34 & 0.36 \\
\hline College and above & 0.22 & 0.22 & 0.04 & 0.29 & 0.02 & 0.03 & 0.01 & 0.01 & 0.26 & 0.34 & 0.10 & 0.20 \\
\hline $\begin{array}{l}\text { Number of people in } \\
\text { the household }\end{array}$ & 3.65 & 3.61 & 3.88 & 3.71 & 4.75 & 5.31 & 3.17 & 4.89 & 3.47 & 3.48 & 2.95 & 3.71 \\
\hline Female & 1.50 & 1.53 & 1.37 & 1.44 & 1.44 & 1.52 & 1.30 & 1.43 & 1.44 & 1.45 & 1.36 & 1.46 \\
\hline Not married & 0.11 & 0.11 & 0.06 & 0.14 & 0.34 & 0.38 & 0.08 & 0.42 & 0.33 & 0.34 & 0.10 & 0.43 \\
\hline $\begin{array}{l}\text { Left the hukou } \\
\text { within } 0.5-3 \text { years }\end{array}$ & & & & & 0.57 & 0.56 & 0.45 & 0.63 & 0.54 & 0.52 & 0.49 & 0.59 \\
\hline $\begin{array}{l}\text { Occupation } \\
\text { Managers, officials }\end{array}$ & 0.04 & 0.05 & 0.02 & 0.04 & 0.02 & 0.03 & 0.02 & 0.01 & 0.06 & 0.10 & 0.04 & 0.02 \\
\hline Technicians & 0.23 & 0.28 & 0.04 & 0.23 & 0.02 & 0.03 & 0.02 & 0.02 & 0.15 & 0.19 & 0.05 & 0.13 \\
\hline $\begin{array}{l}\text { Administrative } \\
\text { staff }\end{array}$ & 0.15 & 0.16 & 0.01 & 0.17 & 0.03 & 0.05 & 0.01 & 0.03 & 0.09 & 0.12 & 0.01 & 0.08 \\
\hline Service staff & 0.26 & 0.18 & 0.64 & 0.27 & 0.34 & 0.25 & 0.64 & 0.29 & 0.45 & 0.33 & 0.71 & 0.47 \\
\hline $\begin{array}{l}\text { Related to } \\
\text { agriculture, } \\
\text { forestry, fishery }\end{array}$ & 0.04 & 0.06 & 0.04 & 0.02 & 0.02 & 0.04 & 0.02 & 0.01 & 0.01 & 0.01 & 0.02 & 0.00 \\
\hline $\begin{array}{l}\text { Related to } \\
\text { manufacture/ } \\
\text { transport }\end{array}$ & 0.27 & 0.27 & 0.26 & 0.28 & 0.56 & 0.60 & 0.30 & 0.63 & 0.25 & 0.25 & 0.17 & 0.29 \\
\hline \multicolumn{13}{|l|}{ Employment status } \\
\hline $\begin{array}{l}\text { Emplovee } \\
\text { Emplover } \\
\text { Self-emploved } \\
\text { Household worker }\end{array}$ & $\begin{array}{l}0.82 \\
0.03 \\
0.13 \\
0.02\end{array}$ & $\begin{array}{l}0.91 \\
0.06 \\
0.00 \\
0.03\end{array}$ & $\begin{array}{l}0.00 \\
0.00 \\
1.00 \\
0.00\end{array}$ & $\begin{array}{l}1.00 \\
0.00 \\
0.00 \\
0.00\end{array}$ & $\begin{array}{l}0.74 \\
0.05 \\
0.19 \\
0.03\end{array}$ & $\begin{array}{l}0.78 \\
0.14 \\
0.00 \\
0.08\end{array}$ & $\begin{array}{l}0.00 \\
0.00 \\
1.00 \\
0.00\end{array}$ & $\begin{array}{l}1.00 \\
0.00 \\
0.00 \\
0.00\end{array}$ & $\begin{array}{l}0.71 \\
0.09 \\
0.17 \\
0.03\end{array}$ & $\begin{array}{l}0.76 \\
0.19 \\
0.00 \\
0.05\end{array}$ & $\begin{array}{l}0.00 \\
0.00 \\
1.00 \\
0.00\end{array}$ & $\begin{array}{l}1.00 \\
0.00 \\
0.00 \\
0.00\end{array}$ \\
\hline \multicolumn{13}{|l|}{ Ownership } \\
\hline Public sector & 0.26 & 0.28 & 0.00 & 0.34 & 0.01 & 0.01 & 0.00 & 0.01 & 0.05 & 0.07 & 0.00 & 0.04 \\
\hline $\begin{array}{l}\text { SOE } \\
\text { Collective owned } \\
\text { enterprises }\end{array}$ & $\begin{array}{l}0.26 \\
0.05\end{array}$ & $\begin{array}{l}0.39 \\
0.06\end{array}$ & $\begin{array}{l}0.00 \\
0.00\end{array}$ & $\begin{array}{l}0.13 \\
0.06\end{array}$ & $\begin{array}{l}0.04 \\
0.03\end{array}$ & $\begin{array}{l}0.05 \\
0.05\end{array}$ & $\begin{array}{l}0.00 \\
0.00\end{array}$ & $\begin{array}{l}0.04 \\
0.03\end{array}$ & $\begin{array}{l}0.10 \\
0.04\end{array}$ & $\begin{array}{l}0.16 \\
0.05\end{array}$ & $\begin{array}{l}0.00 \\
0.00\end{array}$ & $\begin{array}{l}0.07 \\
0.05\end{array}$ \\
\hline $\begin{array}{c}\text { Family business } \\
\text { (registered) }\end{array}$ & 0.19 & 0.07 & 0.82 & 0.15 & 0.35 & 0.22 & 0.79 & 0.28 & 0.35 & 0.21 & 0.89 & 0.27 \\
\hline Private enterprises & 0.12 & 0.10 & 0.00 & 0.23 & 0.34 & 0.36 & 0.00 & 0.47 & 0.32 & 0.33 & 0.00 & 0.45 \\
\hline Other work unit & 0.04 & 0.04 & 0.00 & 0.04 & 0.13 & 0.26 & 0.00 & 0.10 & 0.10 & 0.16 & 0.00 & 0.08 \\
\hline Others & 0.07 & 0.06 & 0.18 & 0.06 & 0.09 & 0.05 & 0.21 & 0.07 & 0.05 & 0.03 & 0.11 & 0.05 \\
\hline Monthly income & 1058 & 1188 & 848 & 902 & 973 & 1100 & 982 & 878 & 152 & 1905 & 1231 & 1133 \\
\hline $\begin{array}{l}\text { Hourly income } \\
\text { Type of contract }\end{array}$ & 6.12 & 7.04 & 4.23 & 5.19 & 4.61 & 5.38 & 4.57 & 4.07 & 8.25 & 10.62 & 6.11 & 5.92 \\
\hline Fixed short term & 0.21 & 0.34 & & 0.00 & 0.34 & 0.94 & & 0.00 & 0.43 & 0.81 & & 0.00 \\
\hline Long term contract & 0.41 & 0.66 & & 0.00 & 0.02 & 0.06 & & 0.00 & 0.10 & 0.19 & & 0.00 \\
\hline No contract & 0.38 & 0.00 & & 1.00 & 0.64 & 0.00 & & 1.00 & 0.47 & 0.00 & & 1.00 \\
\hline $\begin{array}{l}\text { No unemployment } \\
\text { insurance }\end{array}$ & 0.69 & 0.63 & 0.94 & 0.78 & 0.95 & 0.88 & 1.00 & 0.98 & 0.76 & 0.63 & 0.95 & 0.90 \\
\hline
\end{tabular}




\begin{tabular}{lllllllllllll}
\hline No pension & 0.45 & 0.38 & 0.77 & 0.55 & 0.89 & 0.76 & 0.98 & 0.96 & 0.61 & 0.44 & 0.79 & 0.81 \\
No medical insurance & 0.46 & 0.41 & 0.81 & 0.52 & 0.85 & 0.71 & 0.94 & 0.93 & 0.64 & 0.48 & 0.84 & 0.83 \\
\hline
\end{tabular}

Source: 1-per cent census data of China (2005). 
Table A4. Summary Statistics for Recent and Non-Recent Migrants

\begin{tabular}{|c|c|c|c|c|}
\hline & \multicolumn{2}{|c|}{ Rural migrants } & \multicolumn{2}{|c|}{ Urban migrants } \\
\hline & Recent & Non recent & Recent & Non Recent \\
\hline Age & 28.3 & 33.5 & 30.7 & 34.5 \\
\hline \multicolumn{5}{|l|}{ Education levels } \\
\hline Primary and below & 0.19 & 0.25 & 0.05 & 0.06 \\
\hline Junior middle school & 0.65 & 0.58 & 0.32 & 0.33 \\
\hline Senior middle school & 0.15 & 0.15 & 0.36 & 0.35 \\
\hline College and above & 0.02 & 0.02 & 0.27 & 0.25 \\
\hline Number of people in the household & 5.27 & 4.06 & 3.60 & 3.31 \\
\hline Female & 1.47 & 1.40 & 1.45 & 1.42 \\
\hline Not married & 0.45 & 0.19 & 0.41 & 0.23 \\
\hline \multicolumn{5}{|l|}{ Employment status } \\
\hline $\begin{array}{l}\text { Emplovee } \\
\text { Emplover } \\
\text { Self-emploved } \\
\text { Household worker }\end{array}$ & $\begin{array}{l}0.80 \\
0.03 \\
0.15 \\
0.02\end{array}$ & $\begin{array}{l}0.65 \\
0.07 \\
0.25 \\
0.04\end{array}$ & $\begin{array}{l}0.75 \\
0.08 \\
0.15 \\
0.02\end{array}$ & $\begin{array}{l}0.67 \\
0.11 \\
0.19 \\
0.03\end{array}$ \\
\hline \multicolumn{5}{|l|}{ Occupation } \\
\hline $\begin{array}{l}\text { Managers, officials, etc. } \\
\text { Technicians } \\
\text { Administrative staff } \\
\text { Service staff } \\
\text { Related to ag, forestrv, fisherv etc. } \\
\text { Related to manufacture/transport/etc. }\end{array}$ & $\begin{array}{l}0.01 \\
0.02 \\
0.03 \\
0.32 \\
0.02 \\
0.60\end{array}$ & $\begin{array}{l}0.03 \\
0.03 \\
0.04 \\
0.38 \\
0.03 \\
0.51\end{array}$ & $\begin{array}{l}0.05 \\
0.15 \\
0.08 \\
0.46 \\
0.01 \\
0.25\end{array}$ & $\begin{array}{l}0.08 \\
0.15 \\
0.09 \\
0.43 \\
0.01 \\
0.24\end{array}$ \\
\hline \multicolumn{5}{|l|}{ Ownership } \\
\hline Public sector & 0.01 & 0.01 & 0.05 & 0.05 \\
\hline $\begin{array}{l}\text { SOE } \\
\text { Collective owned enterprises } \\
\text { Self-emploved } \\
\text { Private enterprises } \\
\text { Other work unit } \\
\text { Others }\end{array}$ & $\begin{array}{l}0.04 \\
0.03 \\
0.32 \\
0.37 \\
0.15 \\
0.08\end{array}$ & $\begin{array}{l}0.04 \\
0.03 \\
0.41 \\
0.30 \\
0.11 \\
0.11\end{array}$ & $\begin{array}{l}0.10 \\
0.04 \\
0.34 \\
0.32 \\
0.11 \\
0.05\end{array}$ & $\begin{array}{l}0.10 \\
0.03 \\
0.36 \\
0.31 \\
0.10 \\
0.05\end{array}$ \\
\hline Monthly income & 901 & 1072 & 1371 & 1715 \\
\hline Hourly income & 4.28 & 5.07 & 7.43 & 9.24 \\
\hline \multicolumn{5}{|l|}{ Type of contract } \\
\hline $\begin{array}{l}\text { Fixed short term contract } \\
\text { Long term contract } \\
\text { No contract }\end{array}$ & $\begin{array}{l}0.34 \\
0.02 \\
0.64\end{array}$ & $\begin{array}{l}0.34 \\
0.02 \\
0.64\end{array}$ & $\begin{array}{l}0.42 \\
0.09 \\
0.49\end{array}$ & $\begin{array}{l}0.44 \\
0.12 \\
0.45\end{array}$ \\
\hline $\begin{array}{l}\text { No unemplovment insurance } \\
\text { No pension }\end{array}$ & $\begin{array}{l}0.95 \\
0.89\end{array}$ & $\begin{array}{l}0.94 \\
0.88\end{array}$ & $\begin{array}{l}0.77 \\
0.63\end{array}$ & $\begin{array}{l}0.75 \\
0.59\end{array}$ \\
\hline No medical insurance & 0.85 & 0.85 & 0.66 & 0.62 \\
\hline
\end{tabular}

Source: 1-per cent census data of China (2005). 


\section{A2. Additional results}

Table A5. Marginal Effects of Multinomial Logit Regressions (urban residents, rural and urban migrants)

\begin{tabular}{|c|c|c|c|c|c|c|}
\hline \multirow{4}{*}{$\begin{array}{l}\text { Age } 16-20 \text { omitted } \\
\text { Age: } 21-25\end{array}$} & \multicolumn{2}{|c|}{ Urban residents } & \multicolumn{2}{|c|}{ Rural migrants } & \multicolumn{2}{|c|}{ Urban migrants } \\
\hline & \multirow{2}{*}{ Self-employed } & \multirow[t]{2}{*}{ No-contract } & \multirow[t]{2}{*}{ Self-employed } & \multirow[t]{2}{*}{ No-contract } & \multirow[t]{2}{*}{ Self-employed } & \multirow[t]{2}{*}{ No-contract } \\
\hline & & & & & & \\
\hline & $0.022^{* * *}$ & $-0.144^{* * *}$ & $0.059^{* * *}$ & $-0.046^{* * *}$ & $0.053^{* * *}$ & $-0.061^{* * *}$ \\
\hline & $(0.005)$ & (0.009) & $(0.006)$ & $(0.006)$ & $(0.015)$ & $(0.014)$ \\
\hline \multirow[t]{2}{*}{ Age: $26-30$} & $0.025^{* * *}$ & $-0.193^{* * *}$ & $0.094^{* * *}$ & $-0.071^{* * *}$ & $0.091^{* * *}$ & $-0.123^{* * *}$ \\
\hline & $(0.005)$ & (0.009) & $(0.007)$ & $(0.008)$ & $(0.015)$ & $(0.016)$ \\
\hline \multirow[t]{2}{*}{ Age: $31-35$} & $0.019^{* * *}$ & $-0.220^{* * *}$ & $0.115^{* * *}$ & $-0.088^{* * *}$ & $0.115^{* * *}$ & $-0.128^{* * *}$ \\
\hline & $(0.005)$ & $(0.009)$ & $(0.007)$ & $(0.008)$ & $(0.015)$ & $(0.017)$ \\
\hline \multirow[t]{2}{*}{ Age: $36-40$} & $0.019^{* * *}$ & $-0.227^{* * *}$ & $0.132^{* * *}$ & $-0.103^{* * *}$ & $0.124^{* * *}$ & $-0.136^{* * *}$ \\
\hline & $(0.005)$ & (0.009) & $(0.007)$ & $(0.009)$ & $(0.016)$ & $(0.019)$ \\
\hline \multirow[t]{2}{*}{ Age: $41-45$} & $0.017^{* * *}$ & $-0.224^{* * *}$ & $0.142^{* * *}$ & $-0.100^{* * *}$ & $0.125^{* * *}$ & $-0.173^{* * *}$ \\
\hline & $(0.005)$ & $(0.009)$ & $(0.007)$ & $(0.010)$ & $(0.016)$ & $(0.020)$ \\
\hline \multirow[t]{2}{*}{ Age: $46-50$} & $0.009^{*}$ & $-0.219^{* * *}$ & $0.154^{* * *}$ & $-0.123^{* * *}$ & $0.116^{* * *}$ & $-0.128^{* * *}$ \\
\hline & $(0.005)$ & $(0.009)$ & $(0.007)$ & $(0.012)$ & $(0.017)$ & $(0.022)$ \\
\hline \multirow[t]{2}{*}{ Age: $51-55$} & 0.001 & $-0.232^{* * *}$ & $0.138^{* * *}$ & $-0.100^{* * *}$ & $0.116^{* * *}$ & $-0.175^{* * *}$ \\
\hline & $(0.005)$ & $(0.010)$ & $(0.008)$ & (0.015) & $(0.017)$ & $(0.026)$ \\
\hline \multirow[t]{2}{*}{ Age: $55-60$} & 0.008 & $-0.204^{* * *}$ & $0.120^{* * *}$ & $-0.103^{* * *}$ & $0.125^{* * *}$ & $-0.075^{* *}$ \\
\hline & $(0.006)$ & $(0.011)$ & $(0.010)$ & $(0.020)$ & $(0.020)$ & $(0.035)$ \\
\hline \multicolumn{7}{|c|}{ Primary and below omitted } \\
\hline \multirow[t]{2}{*}{ Junior middle school } & $-0.033^{* * *}$ & $-0.013^{* *}$ & $-0.029^{* * *}$ & $-0.089^{* * *}$ & $-0.029^{* * *}$ & $-0.063^{* * *}$ \\
\hline & $(0.002)$ & $(0.005)$ & $(0.002)$ & $(0.005)$ & $(0.007)$ & $(0.018)$ \\
\hline \multirow[t]{2}{*}{ Senior middle school } & $-0.089^{* * *}$ & $-0.082^{* * *}$ & $-0.050^{* * *}$ & $-0.177^{* * *}$ & $-0.073^{* * *}$ & $-0.169^{* * *}$ \\
\hline & $(0.002)$ & $(0.005)$ & $(0.004)$ & $(0.006)$ & $(0.008)$ & $(0.018)$ \\
\hline \multirow[t]{2}{*}{ College and above } & $-0.214^{* * *}$ & $-0.071^{* * *}$ & $-0.109^{* * *}$ & $-0.237^{* * *}$ & $-0.147^{* * *}$ & $-0.285^{* * *}$ \\
\hline & $(0.002)$ & $(0.005)$ & $(0.011)$ & $(0.014)$ & $(0.009)$ & $(0.019)$ \\
\hline \multirow[t]{2}{*}{ Not married } & $-0.032^{* * *}$ & $0.032^{* * *}$ & $-0.121^{* * *}$ & $0.089^{* * *}$ & $-0.077^{* * *}$ & $0.079^{* * *}$ \\
\hline & $(0.002)$ & $(0.004)$ & $(0.004)$ & $(0.006)$ & $(0.007)$ & $(0.010)$ \\
\hline \multirow[t]{2}{*}{ Female } & $-0.017^{* * *}$ & $0.029^{* * *}$ & $-0.049^{* * *}$ & -0.001 & $-0.014^{* * *}$ & $0.029^{* * *}$ \\
\hline & $(0.001)$ & $(0.002)$ & $(0.002)$ & $(0.003)$ & $(0.004)$ & $(0.007)$ \\
\hline Observations & 219712 & & 94621 & & 22214 & \\
\hline
\end{tabular}

$*{ }^{* *},{ }^{* *}$ statistically significant at the $10 \%, 5 \%, 1 \%$ levels, respectively.

a) Samples include those aged 16-60 years old and who are out of school. Observations of migrants who migrated for reasons not related to employment were dropped.

b) The base category in the multinomial logit is formal employment. Regional dummies are included in the regressions but not reported.

c) Standard errors are reported in brackets.

Source: 1-per cent census data of China (2005). 
Table A6. Marginal Effects for Multinomial Logit Results (recent vs. non-recent migrants)

\begin{tabular}{|c|c|c|c|c|c|c|c|c|}
\hline & \multicolumn{4}{|c|}{ Rural migrants } & \multicolumn{4}{|c|}{ Urban migrants } \\
\hline & \multicolumn{2}{|c|}{ Non-Recent } & \multicolumn{2}{|c|}{ Recent } & \multicolumn{2}{|c|}{ Non-Recent } & \multicolumn{2}{|c|}{ Recent } \\
\hline & $\begin{array}{c}\text { Self- } \\
\text { employed }\end{array}$ & No-contract & $\begin{array}{c}\text { Self- } \\
\text { employed }\end{array}$ & No-contract & $\begin{array}{c}\text { Self- } \\
\text { employed }\end{array}$ & No-contract & $\begin{array}{c}\text { Self- } \\
\text { employed }\end{array}$ & No-contract \\
\hline & $\mathrm{dp} / \mathrm{dx}$ & $\mathrm{dp} / \mathrm{dx}$ & $\mathrm{dp} / \mathrm{dx}$ & $\mathrm{dp} / \mathrm{dx}$ & $\mathrm{dp} / \mathrm{dx}$ & $\mathrm{dp} / \mathrm{dx}$ & $\mathrm{dp} / \mathrm{dx}$ & $\mathrm{dp} / \mathrm{dx}$ \\
\hline & s.e. & s.e. & s.e. & s.e. & s.e. & s.e. & s.e. & s.e. \\
\hline $\begin{array}{l}\text { Age } 16-20 \\
\text { omitted }\end{array}$ & & & & & & & & \\
\hline Age: $21-25$ & $\begin{array}{l}0.024 \\
(0.018)\end{array}$ & $\begin{array}{l}-0.072^{* * *} \\
(0.015)\end{array}$ & $\begin{array}{l}0.044^{* * *} \\
(0.005)\end{array}$ & $\begin{array}{l}-0.029^{* * *} \\
(0.007)\end{array}$ & $\begin{array}{l}0.065 \\
(134.035)\end{array}$ & $\begin{array}{l}-0.063 \\
(35.751)\end{array}$ & $\begin{array}{l}0.050^{* * *} \\
(0.014)\end{array}$ & $\begin{array}{l}-0.056^{* * *} \\
(0.017)\end{array}$ \\
\hline Age: 26-30 & $\begin{array}{l}0.082^{* * *} \\
(0.019)\end{array}$ & $\begin{array}{l}-0.106^{* * *} \\
(0.016)\end{array}$ & $\begin{array}{l}0.063^{* * *} \\
(0.006)\end{array}$ & $\begin{array}{l}-0.041^{* * *} \\
(0.009)\end{array}$ & $\begin{array}{l}0.120 \\
(247.253)\end{array}$ & $\begin{array}{l}-0.119 \\
(64.895)\end{array}$ & $\begin{array}{l}0.078^{* * *} \\
(0.015)\end{array}$ & $\begin{array}{l}-0.118^{* * *} \\
(0.020)\end{array}$ \\
\hline Age: $31-35$ & $\begin{array}{l}0.119^{* * *} \\
(0.019)\end{array}$ & $\begin{array}{l}-0.126^{* * * *} \\
(0.016)\end{array}$ & $\begin{array}{l}0.072^{* * *} \\
(0.006)\end{array}$ & $\begin{array}{l}-0.051^{* * *} \\
(0.010)\end{array}$ & $\begin{array}{l}0.157 \\
(324.047)\end{array}$ & $\begin{array}{l}-0.129 \\
(93.749)\end{array}$ & $\begin{array}{l}0.091^{* * *} \\
(0.016)\end{array}$ & $\begin{array}{l}-0.117^{* * *} \\
(0.023)\end{array}$ \\
\hline Age: $36-40$ & $\begin{array}{l}0.147^{* * *} \\
(0.019)\end{array}$ & $\begin{array}{l}-0.151^{* * *} \\
(0.017)\end{array}$ & $\begin{array}{l}0.082^{* * *} \\
(0.006)\end{array}$ & $\begin{array}{l}-0.050^{* * *} \\
(0.011)\end{array}$ & $\begin{array}{l}0.167 \\
(345.079)\end{array}$ & $\begin{array}{l}-0.123 \\
(104.560)\end{array}$ & $\begin{array}{l}0.098^{* * *} \\
(0.016)\end{array}$ & $\begin{array}{l}-0.139^{* * *} \\
(0.025)\end{array}$ \\
\hline Age: $41-45$ & $\begin{array}{l}0.163^{* * *} \\
(0.019)\end{array}$ & $\begin{array}{l}-0.137^{* * *} \\
(0.018)\end{array}$ & $\begin{array}{l}0.087^{* * *} \\
(0.006)\end{array}$ & $\begin{array}{l}-0.062^{* * *} \\
(0.013)\end{array}$ & $\begin{array}{l}0.165 \\
(341.120)\end{array}$ & $\begin{array}{l}-0.171 \\
(87.419)\end{array}$ & $\begin{array}{l}0.100^{* * *} \\
(0.017)\end{array}$ & $\begin{array}{l}-0.159^{* * *} \\
(0.028)\end{array}$ \\
\hline Age: $46-50$ & $\begin{array}{l}0.179^{* * *} \\
(0.020)\end{array}$ & $\begin{array}{l}-0.174^{* * *} \\
(0.020)\end{array}$ & $\begin{array}{l}0.098^{* * *} \\
(0.007)\end{array}$ & $\begin{array}{l}-0.066^{* * *} \\
(0.017)\end{array}$ & $\begin{array}{l}0.154 \\
(318.297)\end{array}$ & $\begin{array}{l}-0.121 \\
(93.774)\end{array}$ & $\begin{array}{l}0.092^{* * *} \\
(0.017)\end{array}$ & $\begin{array}{l}-0.118^{* * *} \\
(0.031)\end{array}$ \\
\hline Age: 51-55 & $\begin{array}{l}0.158^{* * *} \\
(0.021)\end{array}$ & $\begin{array}{l}-0.167^{* * *} \\
(0.023)\end{array}$ & $\begin{array}{l}0.087^{* * * *} \\
(0.008)\end{array}$ & $\begin{array}{l}-0.018 \\
(0.021)\end{array}$ & $\begin{array}{l}0.162 \\
(335.117)\end{array}$ & $\begin{array}{l}-0.158 \\
(89.152)\end{array}$ & $\begin{array}{l}0.088^{* * *} \\
(0.019)\end{array}$ & $\begin{array}{l}-0.184^{* * *} \\
(0.037)\end{array}$ \\
\hline Age: 55-60 & $\begin{array}{l}0.163^{* * *} \\
(0.024)\end{array}$ & $\begin{array}{l}-0.198^{* * *} \\
(0.030)\end{array}$ & $\begin{array}{l}0.051^{* * *} \\
(0.011)\end{array}$ & $\begin{array}{l}-0.000 \\
(0.029)\end{array}$ & $\begin{array}{l}0.206 \\
(426.133)\end{array}$ & $\begin{array}{l}-0.094 \\
(147.299)\end{array}$ & $\begin{array}{l}0.046^{*} \\
(0.026)\end{array}$ & $\begin{array}{l}-0.036 \\
(0.051)\end{array}$ \\
\hline $\begin{array}{l}\text { Primary and } \\
\text { below } \\
\text { omitted } \\
\text { Junior }\end{array}$ & & & & & & & & \\
\hline $\begin{array}{l}\text { middle } \\
\text { school }\end{array}$ & $\begin{array}{l}-0.041^{* * *} \\
(0.005)\end{array}$ & $\begin{array}{l}-0.071^{* * *} \\
(0.007)\end{array}$ & $\begin{array}{l}-0.021^{* * *} \\
(0.003)\end{array}$ & $\begin{array}{l}-0.097^{* * *} \\
(0.007)\end{array}$ & $\begin{array}{l}-0.031 \\
(64.458)\end{array}$ & $\begin{array}{l}-0.047 \\
(41.861)\end{array}$ & $\begin{array}{l}-0.027^{* * *} \\
(0.010)\end{array}$ & $\begin{array}{l}-0.084^{* * *} \\
(0.027)\end{array}$ \\
\hline $\begin{array}{l}\text { Senior } \\
\text { middle } \\
\text { school }\end{array}$ & $-0.081^{* * *}$ & $-0.143^{* * *}$ & $-0.035^{* * *}$ & $-0.189^{* * *}$ & -0.087 & -0.137 & $-0.062^{* * *}$ & $-0.206^{* * *}$ \\
\hline & $(0.007)$ & $(0.009)$ & $(0.004)$ & $(0.008)$ & (179.533) & (118.145) & $(0.010)$ & $(0.027)$ \\
\hline $\begin{array}{l}\text { College and } \\
\text { above }\end{array}$ & $\begin{array}{l}-0.210^{* * *} \\
(0.022)\end{array}$ & $\begin{array}{l}-0.153^{* * *} \\
(0.021)\end{array}$ & $\begin{array}{l}-0.054^{* * *} \\
(0.011)\end{array}$ & $\begin{array}{l}-0.276^{* * *} \\
(0.018)\end{array}$ & $\begin{array}{l}-0.177 \\
(366.213)\end{array}$ & $\begin{array}{l}-0.238 \\
(228.109)\end{array}$ & $\begin{array}{l}-0.122^{* * *} \\
(0.011)\end{array}$ & $\begin{array}{l}-0.334^{* * *} \\
(0.028)\end{array}$ \\
\hline Not married & $\begin{array}{l}-0.158^{* * *} \\
(0.009)\end{array}$ & $\begin{array}{l}0.122^{* * *} \\
(0.009)\end{array}$ & $\begin{array}{l}-0.090^{* * *} \\
(0.004)\end{array}$ & $\begin{array}{l}0.053^{* * *} \\
(0.008)\end{array}$ & $\begin{array}{l}-0.085 \\
(174.859)\end{array}$ & $\begin{array}{l}0.098 \\
(41.425)\end{array}$ & $\begin{array}{l}-0.069^{* * *} \\
(0.008)\end{array}$ & $\begin{array}{l}0.055^{* * *} \\
(0.015)\end{array}$ \\
\hline Female & $\begin{array}{l}-0.065^{* * *} \\
(0.004)\end{array}$ & $\begin{array}{l}0.013^{* *} \\
(0.005)\end{array}$ & $\begin{array}{l}-0.037^{* * *} \\
(0.002)\end{array}$ & $\begin{array}{l}-0.013^{* * *} \\
(0.004)\end{array}$ & $\begin{array}{l}-0.018 \\
(36.313)\end{array}$ & $\begin{array}{l}0.014 \\
(10.786)\end{array}$ & $\begin{array}{l}-0.011^{* *} \\
(0.005)\end{array}$ & $\begin{array}{l}0.041^{* * *} \\
(0.010)\end{array}$ \\
\hline Observations & 40080 & & 54541 & & 10407 & & 11807 & \\
\hline
\end{tabular}

$*, * * * * *$ statistically significant at the $10 \%, 5 \%, 1 \%$ levels, respectively.

a) Samples include those aged 16-60 years old and who are out of school. Observations on migrants who migrated for reasons not related to employment were dropped.

b) The base category in the multinomial logit is formal employment. Regional dummies are included in the regressions but not reported. c) Standard errors are reported in brackets.

Source: 1-per cent census data of China (2005). 
Figure A2. Average monthly income and percentage of workers without a formal contract

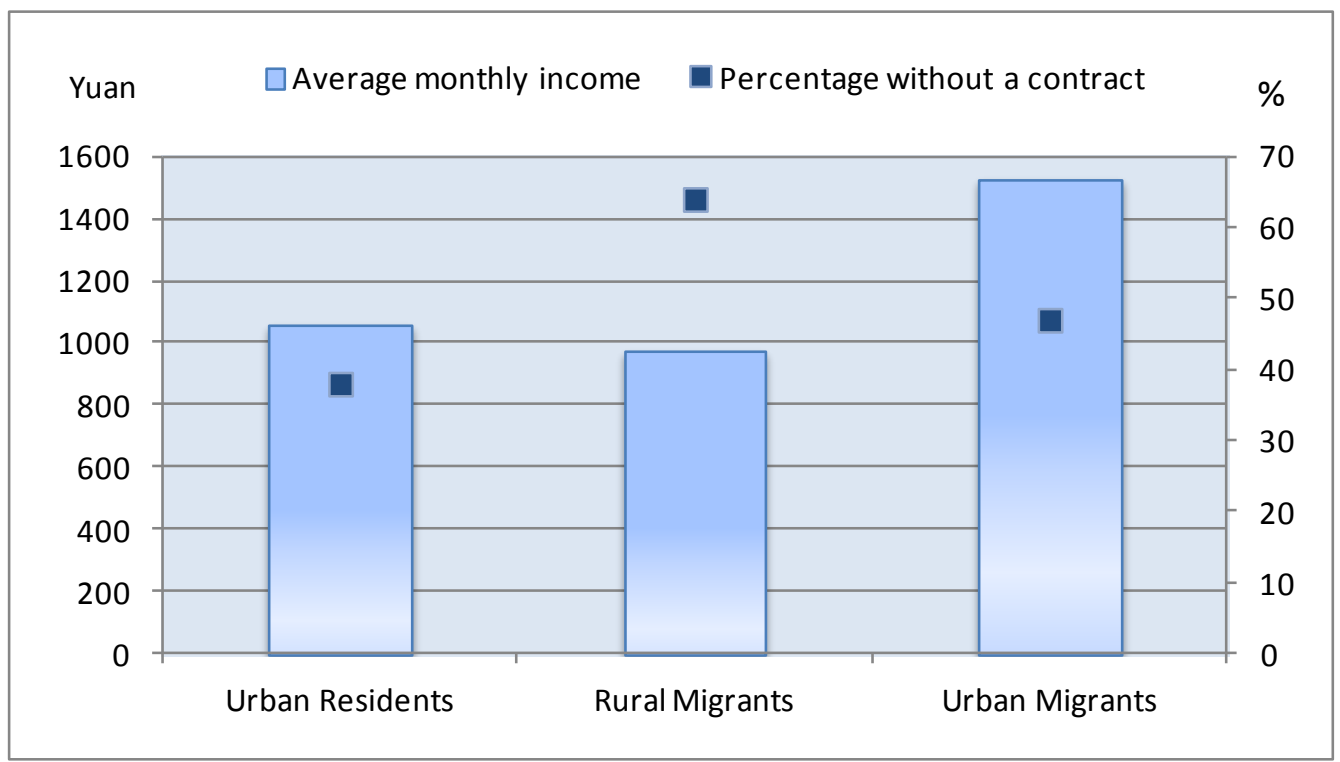

Source: 1-per cent census data of China (2005). 